\title{
A propòsit del Llibre de fra Bernat
}

\author{
JOSEP-ANTONI YSERN
}

(UNED)

Juan de Mairena afirmava, amb la seva saviesa irònica i aguda (Machado 1981: 43): «La blasfemia forma parte de la religión popular. Desconfiad de un pueblo donde no se blasfema [...].» Sens dubte, el nostre poble és dels més dignes de confiança. Josep Pla, tot dolent-se'n, afirma (Pla 2001: 35): «Enlloc no he sentit blasfemar com en aquesta península. S'hi blasfema d'una manera única: amb naturalitat. D'una manera tan baixa, fisiològica i catabòlica, potser només a Itàlia —i encara!»

No sé si la blasfèmia, però almenys sí la verbalització artística - lato sensu $\mathrm{i}$ enginyosa de la irreligiositat i de l'anticlericalisme de divers voltatge ha estat un dels nostres deports - no dic pas esports - tradicionals. Si molt convé, el costum comença a decaure ara, precisament perquè vivim, gràcies a Déu, en una societat fortament secularitzada, on la llibertat religiosa ha propiciat ja un canvi de codis culturals que fan quasi inviables aquestes pràctiques literàries. Potser, bo i seguint el fil dels comentaris de Pla, l'actual falta de familiaritat amb la divinitat, ha llevat una certa força a aquest vell costum. ${ }^{1}$

Tot i així, sembla que en l'àmbit popular sí que han persistit algunes mostres de literatura anticlerical i irreverent, com demostra l'interessant treball d'Antonio Lorenzo (1997), que recull i estudia una àmplia selecció de contes i acudits d'aquest to a partir de l'actual tradició oral castellana. ${ }^{2}$ Per això no ha de

${ }^{1}$ Pla (2001: 36-37): «Ens han habituat a creure que totes les coses de la nostra vida - fins les més baixament fisiològiques i materials - depenen de Déu. [...] Aquesta pueril, falsa i ridícula habitualitat ens porta a fer-lo responsable de tot el que hem estat, som i serem. Així, si les coses ens van bé, ho trobem tot d'una magnanimitat prodigiosa. A la primera dificultat, però, la protesta brutal fatalment es produeix. Tinc la convicció que si no s'hagués comès la insensatesa d'acostar-lo tant el respectaríem més i renegaríem menys. La naturalitat del renec indígena ho demostra plenament». Agraeixo al prof. Josep Murgades (UB) que m'animés a resseguir les reflexions planianes al respecte d'aquest tema, arran d'una exposició pública d'una primera versió d'aquest treball.

2 Algun dia hom haurà d'estudiar la creació d'un folklore ja no de tradició oral, ans electrònica! No debades el làbil món d'Internet ha permès la reentrada de bona cosa d'aquest material volàtil. Així, Lorenzo (1997: 144) selecciona l'anècdota del «Cura hinchao", que narra el cas d'un capellà dut a un hospital «hinchao, hinchao como una bota, del vientre». L'operen i els metges, per 
sorprendre'ns que un poeta com Josep Maria de Sagarra, un dels nostres poetes més populars — volgudament popular (Fuster 1985: 219)—, no s'hagi abstingut de practicar el tema amb la Balada de fra Rupert, protagonitzada per un religiós que potser s'avindria d'allò millor amb el fra Bernat de qui parlarem en aquestes pàgines.

Segons sembla, rere aquest fra Rupert s'amaga un predicador famós, conegut de Sagarra, el qual el converteix en protagonista d'una divertida balada, tan obscena com, segons per a qui, divertida. Fixem-nos ni que sigui només en la introducció narrativa, en la qual es presenta l'acció protagonitzada per fra Rupert: ${ }^{3}$

Fra Rupert, de les dames predilecte, menoret d'aparell extraordinari, puja a la trona amb el ninot erecte i com aquell que va a passar el rosari, sense gota ni mica de respecte als vots del venerable escapulari, mostrant impúdic el que té entre cames excita la lascívia de les dames. I amb veu entre baríton i tenor canta Rupert, l'impúdic fra menor:

Gustós, senyores, m'avinc a explicar-vos com els tinc.

Efectivament, ho conta. Tota la resta de la llarga balada és una descripció de com els té en comparació amb els religiosos d'altres ordes, citats en còmics apariats: «Els tinc grossos i rodons / com els pares Felipons. // Els tinc nets i sense tites / com els Padres Jesuittes. // Els tinc frescos i bonics / com els Pares Dominics. // Cadascun em pesa un quilo / com els del Pare Camilo. // Se'ls podria portar amb palmes / com aquells del Mestre Balmes. // No els tinc tous ni tampoc nanos, / com els tenen els hermanos. // Ni plens d'innoble mengia / com els del Cor de Maria. // Ni tenen les bosses tristes / com els dels Germans Maristes. // I no em ballen nit i dia / com els de l'Escola Pia. // No són els grans de rosaris / que pengen als Trinitaris.» I així successivament, amb algunes apreciacions que ultrapassen la pura descripció, com quan es refereix als dels seminaristes, als dels novicis o al dels missioners.

rifar-se'n, li fan creure que li n'han extret un nadó, que li ensenyen. El pobre capellà s'exclama: «- ¡Hay que ver!, ¡pa la primera vez que me dieron por culo me quedé preñao!» I el narrador conclou: «Le sacaron en claro que era maricón el cura». Una variació d'aquesta anècdota ha circulat per l'hiperespai en versió més dramatitzada: el capellà cria l'infant, fent-lo passar per nebot seu, i, amb els anys, en arribar al punt de la mort, el crida a la seva vora. Decideix contar-li el fet i el jove, en veure la vergonya que passa el capellà, li diu: «-Tranquilo tío, no hace falta, desde hace años ya me he imaginado que en realidad es usted mi padre». El sacerdot, llavors, fent el cor fort, li amolla: «- No!... Yo soy tu madre.... ¡Tu padre es el arzobispo!»

${ }^{3}$ Cito el text segons Sagarra (2003: 66-71), editat per Permanyer, qui aporta (ibid. pp. 64-65) la notícia al respecte del referent real d'aquest personatge així com a les circumstàncies del recital d'aquest poema, que esmento més avall. 
Tota la composició acaba amb un toc d'ufanós optimisme, quan fra Rupert, potser ja una mica fatxendejant, afirma:

No hi ha al món un tal encert com els ous de fra Rupert.

La que els toqui amb vehemència, cinc-cents dies d'indulgència.

La que en copsi la grandària, fins indulgència plenària.

I el cul que no els és rebel anirà del llit al cel.

\author{
No té l'Església Romana \\ cosa més noble i més sana, \\ ni té l'ordre Caputxina \\ peça més pulcra i més fina, \\ disposada a tot servei \\ Ad Majorem Gloriam Dei.
}

Sembla que la recitació, seguit seguit d'una conferència de Federico García Lorca, fou un èxit clamorós; tant que Margarida Xirgu, present en tal avinentesa, el va recitar de bell nou i el poeta andalús, segons diuen, s'exclamà: «iQué grande eres, Margarita! Con una actriz como tú y un poeta como Sagarra, la lengua catalana no morirá nunca».

Aquesta literatura d'esplai, amb més o menys força crítica, ha seduït també autors coneguts per la seva literatura seriosa. L'atracció és constant, però és més i més freqüent segons ens acostem al Renaixement. Recordem, per exemple, com Bernat Metge escriu Lo somni, però també el Sermó o la Medecina. O, més tard, com un Narcís Vinyoles o un Jaume Gassull o bé un Bernat Fenollar poden tenir poesies religioses i alhora participar en Lo procés de les olives. Encara no s'arriba, però, al polifacetisme d'un Gianfrancesco Poggio, humanista, secretari pontifici de diversos papes, autor de diàlegs en llatí, descobridor d'obres de l'antiguitat clàssica, i autor, sobretot, d'un Liber facetiarum, que és un recull de narracions moltes d'elles tan picants com divertides; i què dir, ja en ple Barroc, d'un Quevedo, capaç d'escriure poesia metafísca, letrillas satíricas i un divertit Gracias y desgracias del ojo del culo.

Ha passat el temps en què aquesta literatura era negligida per la crítica, per motius del tot subjectius, ${ }^{4}$ i crec que és saludable tenir-la present i llegir-la en paral-lel a la dels autors de primera fila: és bo, a fi de completar la visió d'una època, acarar les cabòries eròtiques i filosòfiques d'un Ausiàs, amb la teologia parda de fra Bernat; com també ho és llegir les aventures i desventures de cavallers

4 Val la pena, en aquest sentit, llegir l'estudi introductori de Victorio (1983), especialment les pp. 9-13, on critica la visió pidaliana d'aquest tipus de literatura, alhora que ofereix un treball amè i d'allò més indicat per a fer una ullada sobre aquesta altra cara de la literatura medieval —bé que en el context castellà-. A hores d'ara, el públic general ja té bones vies d'acostament a aquesta literatura de caire més o menys obscè, picant, vitalista o com vulgueu dir-ne, tant medieval com posterior. Potser només a títol informatiu, convé esmentar, pel que fa al castellà, les importants antologies de poesia eròtica àuria d'Alzieu+Jammes+Lissorgues (1984) i de Díez (2003), amb la interssant aportació d'Urbano (1999) sobre lírica folklòrica. Com a panorama general de la poesia eròtica en castellà — des de l'Edat Mitjana fins a l'actualitat--, és molt recomanable l'antologia de Provencio (2003) - . D'altra banda, els coneguts treballs de Cela $(1989,1994)$ subministren materials també d'interès. La bibliografia catalana bàsica la indico més avall, a l'inici del punt II. 
com Tirant o Curial i, alhora, l'amarga peripècia d'un cavaller real, implicat en un cas de corrupció de menors, com es llegeix en el procés judicial donat a conèixer per Jaume Riera amb el títol d'El cavaller i l'alcavota.

\section{La hipocresia, en el punt de mira de la crítica anticlerical}

Caro Baroja (1985: 189-191), en parlar de l'anticlericalisme en la societat espanyola dels segles XVI-XVII, distingeix entre posicions radicals i d'altres de més suaus, entre l'anticlericalisme dels intel-lectuals i el dels incultes, entre les autocrítiques - de vegades molt dures- del clergat mateix i les crítiques externes, sense oblidar les derivades de simples rivalitats intraeclesiàstiques. ${ }^{5}$ Tot plegat fa veure que sota l'etiqueta d'anticlericalisme s'amaguen fenòmens molt complexos, no sempre interpretables des d'una mateixa perspectiva i que tenen en comú, més aviat, només el destinatari de la crítica, ja que el contingut d'aquesta, la seva intensitat i força revulsiva —si en té-, poden ser molt diferents. ${ }^{6}$

D'altra banda, l'esmentat erudit revisa amb gran detall -i no sense un gra d'ironia - un ric ventall de documentació, majorment en castellà, de l'època àuria - des de sermons fins a dramatúrgia-, però, de fet, els temes, el to de blasme, el sarcasme o la ironia dels textos que selecciona, no són privatius, lògicament, del barroc castellà.

De fet, en la variadíssima producció sermonària de S. Vicent Ferrer podem espigolar no pocs testimonis de crítica contra la corrupció moral del clergat. ${ }^{7}$ Així, un dels pecats que denuncia amb més insistència Ferrer és el de l'avarícia dels religiosos, falta que, d'altra banda, pot induir a certes pràctiques supersticioses condemnables, com ara les misses de sant Amador:

Mas molts hi erren, que fan contra Déu, RELIGIOSOS E PREVERES E D'ALTRES, QUE NO-LS VA LO COR SINÓ EN LA AVARíCIA de aquest món, que fan SIMONIA. Axí com hun prevere dirà per avarícia al pacient que face dir les MISSES DE SENT

${ }^{5}$ Certament, la tradició de la literatura de caire anticlerical és ben llarga i variada. Qui hi tingui interès podrà fer-ne un primer tast en l'antologia preparada per Bravo (2001), qui recull textos des de l'Antiguitat fins a l'actualitat — si bé el criteri que sustenta l'obra no és del tot clar i la tria de textos, com en qualsevol antologia, pot semblar discutible-.

${ }^{6}$ Caro Baroja (1985: 190): «Encontraremos, en primer lugar, textos en que los vicios se reprueban en general, aunque particularmente el que los reprueba se cura en salud, mediante salvedades, restricciones, etc. En segundo lugar, otros en que se ve que el autor toma una posición más radical y parece dar a entender que tales vicios son congénitos en el clero. En tercer término, hallaremos textos de varones muy metidos en la vida religiosa, católica, que hacen críticas con significado exhortatorio, aunque, a veces, parece también que los que exhortan a penitencia gozan con la contemplación de los vicios de rivales o enemigos».

$7 \mathrm{Al}$ meu parer, la millor antologia temàtica de l'obra de S. Vicent Ferrer continua essent la de Chabás (1902-1903, reed. 1995). Narbona (1992: 79-124), però, dedica unes pàgines fonamentals a la descripció de la càrrega moral de la predicació vicentina, força documentades i ben contextualitzades, en el marc del seu estudi de la societat valenciana dels ss. XIV-XV vista a través de les ordenances del Consell municipal, de la documentació generada per l'acció del Justícia Criminal i, lògicament, dels sermons del nostre dominic-. 
AMADOR, e que.y hage tantes candeles e que.y hage un diner, e que.s diguen contínuament, a ben créxer la fava. Oo, quinya error! La primera és que per aquelles misses isque l'ànima del purgatori. Veritat és que la ànima de sa mare, de sent Amador, n'isqué, per ço que ere en tal condició que allò li valgué; mas no.u farà a hun altre, que una medicina no pot ésser general a totes malalties. [...] Sent Amador ere molt sant, e per allò per aventura salvà la ànima de son pare e de sa mare. Item, hi ha altre error, que les misses diu que són tantes de la Trinitat, tantes de senta Maria Magdalena, etc; e diu que-s deuen dir arreu. [...] ALTRA ERROR: DELS DINERS E DE LES CANDELES QUE.Y FAN METRE, QUE MUNTEN X O XII SOUS. AÇÒ SIMONIA ES E GRAN ERROR, E PER RES NO PODEN VALER TALS MISSES. [...] E, per semblant, vosaltres lechs peccau, que.ls hi feu caure als preveres. [S III, 181-182, 6-12]

Independentment que, en aquest cas, l'orador sembla responsabilitzar els llecs del pecat dels preveres, l'avarícia és una de les taques més típiques en el curriculum dels qui fan de la virtut llur pretesa professió, mirat almenys des de la perspectiva de la massa popular. Margit Frenk (2006: 316-328), en un divertit estudi dedicat a la imatge dels capellans i dels frares en el cançoner popular del Segle d'Or castellà recull petites joies tan eloqüents com aquesta (ibid. p. 317318): « ¡Ay, Señor!, y tú lo ve / en cuál casa hay más dinero: / ¡en casa del crego [= clergue]!» I hi afegeix l'explicació del Diccionario de autoridades (s. v. 'abad'): «Refrán con que se reprende a los que quieren mantenerse y vivir sin que les cueste trabajo». Al cap i a la fi, encara avui dia diem "viure com un retor'» com a al-lusió al fet de viure regaladament. Al marge de si això continua essent cert o no, el que és inqüestionable és que la reacció irònica i sarcàstica al respecte és molt antiga i ens arriba ben documentada. Recordem almenys els goliards amb la composició pertanyent als Carmina Burana, que comença «Manus ferens munera / pium facit impium», i que va narrant tot el que poden fer els diners ${ }^{8}$ d'una manera que recorda - no per casualitat - el famós fragment de Turmeda conegut com l'elogi dels diners, inclòs en el Libre de bons amonesta. ments, ${ }^{9}$ i que pertany a una línia temàtica que trobem també documentada en l'Enxiemplo de la propiedat quel dinero ha, de l'Arxiprest d'Hita (Ruiz 1990: 261-272) $)^{10} \mathrm{o}$ bé en reelaboracions tardanes, com les letrillas satíricas del barroc

${ }^{8}$ Hilka + Schumann (1930: I, 1-2, comentari: II, 1-4): «Manus ferens munera /pium facit impium; / nummus iungit federa, / nummus dat consilium; / nummus lenit aspera, / nummus sedat prelium. / nummus in prelatis / est pro iure satis; / nummo locum datis / vos, qui iudicatis. // Nummus ubi loquitur, / fit iuris confusio; / pauper retro pellitur, / quem defendit ratio, / sed dives attrahitur / pretiosus pretio. / hunc iudex adorat, / facit, quod implorat; / pro quo nummus orat, / explet, quod laborat".

${ }_{9}$ Em refereixo als arxiconeguts versos que comencen «Diners fan bé, diners fan mal, / diners fan l'home infernal / e fan-lo sant celestial, / segons que els usa» i que inclouen afirmacions tan contundents com «Diners, doncs, vulles aplegar. / Si els pots haver no els lleixs anar; / si molt n'hauràs poràs tornar / papa de Roma. // Si vols haver bé e no dan / per advocat té sent «jo ha'n». / Totes coses per ell se fan, / en esta vida». Veg. Metge + Turmeda (1927: 154-155).

${ }^{10}$ Recordem que, després d'una introducció general sobre els diners (est. 490-492), ve una llarga tirada que satiritza la relació dels religiosos amb aquests (est. 493-507). La cuaderna vía 493 sintetitza admirablement la idea que desenvolupa l'evangeli segons S. Marc d'Argent, que veurem tot seguit: «Yo vi en corte de Roma, do es la santidat, / que todos al dinero fazen grand omildat; / grand 
castellà signades per Góngora («Dineros son calidad») ${ }^{11}$ o Quevedo («Poderoso caballero / es don dinero»). ${ }^{12}$ Els tòpics sobre els quals es basteixen tots aquests poemes es troben ben recollits en un altre text goliàrdic sobre el qual vull cridar l'atenció. Em refereixo a l'Initium sancti Evangelii secundum Marcas Argenti, que copio tot seguit (García-Villoslada 1975: 327):

In illo tempore dixit Papa Romanis: «Cum venerit filius hominis ad sedem maiestatis nostrae, primum dicite: «Amice, ad quid venisti?» At ille si perseveraverit pulsans NIL DANS VOBIS, eicite eum in tenebras exteriores.» Factum est autem, ut quidam PAUPER CLERICUS veniret ad curiam domini Papae, et exclamavit dicens: «Miseremini mei saltem vos, ostiarii Papae, quia manus paupertatis tetigit me. EGO VERO EGENUS ET PAUPER SUM, IDEO PETO, UT SUBVENIATIS CALAMITATI ET MISERIAE MEAE.» Illi autem audientes indignati sunt valde et dixerunt: «Amice, PAUPERTAS TUA TECUM SIT IN PERDITIONE, vade retro, Sathanas, quia non sapis ea, quae sapiunt nummi. Amen, amen, dico tibi: non intrabis in gaudium domini tui, donec dederis novissimum quadrantem.»

Pauper vero abiit et vendidit pallium et tunicam et universa quae habuit, et dedit cardinalibus et ostiariis et camerariis. At illi dixerunt: «Et hoc quid est inter tantos?» Et eiecerunt eum ante fores, et egressus foras flevit amare et non habens consolationem. Postea venit ad curiam quidam CLERICUS DIVES, INCRASSATUS, IMPINGUATUS, DILATATUS, QUI PROPTER SEDITIONEM FECERAT HOMICIDIUM. Hic primo DEDIT ostiario, secundo camerario, tertio cardinalibus. At illi arbitrati sunt inter eos, quod essent plus accepturi. Audiens autem dominus Papa cardinales et ministros plurima dona a clerico accepisse, infirmatus est usque ad mortem. Dives vero misit sibi ELECTUARIUM AUREUM ET ARGENTEUM, et statim sanatus est. Tunc dominus papa ad se vocavit cardinales et ministros et dixit eis: «Fratres, videte, ne aliquis vos seducat inanibus verbis. Exemplum enim do vobis, ut, quemadmodum ego capio, ita et vos capiatis.»

onra le fazían con grand solenidat: / todos a él se enclinavan, como a la magestat». Tampoc no oblida Juan Ruiz notar la hipocresia dels religiosos pel que fa als diners (est. 503): «Yo vi a muchos monges en sus pedricaciones / denostar al dinero e asus tentaçiones, / en cabo, por dinero otorgan los perdones, / asuelven el ayuno e fazen oraçiones». Aquesta idea és desenvolupada al llarg de quatre estrofes següents.

11 Es tracta de la letrilla núm. 17 (Góngora 1980: 93-97), que no té al-lusions antoiclericals, però sí desenvolupa els grans tòpics sobre el poder dels diners: «Cruzados hacen cruzados, / escudos pintan escudos, / y tahúres muy desnudos / con dados ganan Condados; / ducados dejan Ducados; / y coronas Majestad: / ¡Verdad!». Tanmateix, la letrilla que segueix - la núm. 18 - (Góngora 1980: 97-99) sí que entra de ple en la línia anticlerical: «Cura que en la vecindad / vive con desenvoltura / ¿para qué llamarlo cura / si es la misma enfermedad?». Entre els tòpics que aprofita, hi ha el de la incontinència sexual dels clergues: «no le llamen reverencia / que se hace paternidad» (vv. 11-12); «y si le llamare Padre / algún rapaz tiernamente / la voz de aquel inocente / misterio encierra y verdad» (vv. 18-21). Val a dir que aquesta darrera configuració tornarem a trobar-la, més avall, en el cançoner popular; de fet, l'editor de les letrillas subratlla, en nota, el caràcter popular de l'anticlericalisme literari de Góngora.

12 Núm. 660, Quevedo (1995: 170-172). De nou es tracta d'una sàtira sobre el poder dels diners, però sense al-lusions anticlericals. 
He subratllat amb VERSALETES els mots clau del text, que en fan palès el sentit: la descripció de la diferent manera com és tractat el pobre que arriba a la cort pontifícia demanant ajuda i sense donar res - «nil dans»- a ningú, perquè res no té, i el ric — gros i homicida-, que hi entra repartint tresors a tothom! Ara bé, l'anècdota guanya un caràcter de denúncia per dos motius: el primer, perquè hom accepta que teòricament la cort pontifícia hauria de ser un model de vida evangèlica, expectativa certament defraudada en aquest text; el segon - $\mathrm{i}$ ací apareix un concepte central en el món de la sàtira i de la invectiva- perquè tot el text es construeix com una paròdia.$^{13}$ Observem, d'entrada, el seu títol: evidentment, el marc al-ludit en aquest nou evangeli no és pas el nom del sant evangelista, ans el de la moneda d'argent — «marcas argenti»- que, nota bene, ocupa el lloc d'un personatge sant $i$, per tant, és també santificat indirectament. De més a més, aquest nou evangeli presenta unes falques estilístiques, que he subratllat, les quals serveixen per a imitar perfectament l'estil dels evangelis canònics: per exemple, l'expressió «in illo tempore»-i variants com «in illis diebus»- és el circumstancial de temps més habitual en els evangelis, especialment en les versions escurçades incloses en els missals, on sovint hom llegeix «in illo tempore dixit Ihesus discipulis suis»: ja només aquest inici evocava directament el model, amb la particularitat que el Papa substitueix ací Jesucrist i els seus cardenals substitueixen els deixebles. El mateix es pot dir d'una expressió com «factum est autem». Fins i tot l'acció narrada evoca tants i tants moments dels evangelis canònics en què pobres, malalts i molts altres marginats s'acosten a Jesucrist tot implorant el seu ajut: com ara ací el pobre que demana misericòrdia.

Però tornem per un moment a S. Vicent Ferrer, encara. No oblidem que parla amb la peremptorietat pròpia del moralista convençut de la proximitat de la fi del món: la situació de crisi que li toca viure, el desballestament general de la societat, el símptoma més evident del qual és el Cisma, l'indueixen a pensar que l'Anticrist ja ha arribat $\longrightarrow$ com explica en una carta adreçada al papa Benet XIII- ${ }^{14}$ i que el seguiment de la seva predicació és gairebé l'última oportunitat de poder comptar-se entre els salvats. La seva visió, doncs, d'un món en descomposició es fa ben palesa mitjançant l'al-legoria del cos místic, ${ }^{15}$ descrit ara com un cos ple de malalties:

${ }_{13}^{13}$ Quant al concepte de paròdia, trobo fonamental, per la claredat de la divertida exposició i per la riquesa dels textos emprats, el treball de Hauf (2000). És també útil pel seu caràcter panoràmic i divulgatiu l'assaig de Moga (2001) dedicat al gènere de la sàtira. En referència a aquest mateix gènere, però centrat en el s. XV castellà, veg. la ja clàssica antologia de Rodríguez (1989). La bibliografia és ampliable facilíssimament a partir dels treballs suara citats i d'altres, però no pretenc més que oferir unes poques vies d'acostament al tema de la sàtira i de la paròdia, fonamentals en el tema que ens ocupa ací.

${ }^{14}$ Tenim aquesta missiva a l'abast en l'edició d'A. Robles (1996: 410-425) i és amplament comentada per S. Fuster (2004: 225-236) en el seu interessant estudi sobre l'Anticrist i el final de la història en Vicent Ferrer.

${ }^{15}$ El cos místic és, potser, una de les metàfores més utilitzades pels teòrics de l'època per a descriure la societat en què vivien i prové de sant Pau, qui afirma (1 Co 12-31): «El Crist és com el cos humà, que és un, encara que tingui molts membres: TOTS ELS MEMBRES, NI QUE SIGUIN MOLTS, FORMEN UN SOL COS. [...] Però Déu ha distribuït en el cos cadascun dels membres de la manera que li ha semblat. Si tot el cos es reduís a un sol membre, on seria el cos? [...] els membres del cos que sem- 
AXÍ ÉS ARA D'AQUEST MÓN, QUE JA ÉS TOT MALALT. E LOS MEMBRES DE AQUEST MÓN SÓN LOS ESTAMENTS DE CHRISTIANDAT. Lo CAP són los senyors, e ja és tot malalt, per ço que no fan justícia (los prelats, fent symonia; si voleu ministrar hun sagrament, tantost ab diners, etc.). Los HUYLLS són los doctors qui mostren als altres; e ara ja són malalts, car, si no·y ha pleyts, ells ne lleven, e.ls nodrexen, e.ls sostenen. Les ORELLES són los confessors qui hoen de confessions; mas ja són molts qui no confesses sinó per haver diners, e no curen de la honor de Déu ne de la salvació de les ànimes. Lo NAS són les persones devotes que odoren les virtuts de Déu; mas ja és malalt que no ho fan sinó per ypocresia. La BOQUA, que ha dos officis, menjar e parlar, signifique dues condicions de gens: la una són los preveres, qui prenen la vianda del sagrament del altar, e dien misses devotament; mas ja és malalta, que no dien missa sinó per diners [...]. L'altre offici que ha la boqua és parlar, e signifique que los preveres deuen dir bé ses Hores; mas ja és malalt, car no dien aquelles, sinó a hu e dos, par «xam, xam», de un vers dos mots ne fan. Los BRAÇOS són los cavallers que deffenen la terra; mas ja són malalts, que axí com ells deurien ajudar als llauradors, ells los roben, etc... Lo vENTRE, qui rep les viandes que hom menge, són los mercaders, qui han la riquea en lo ventre de l'archa; mas ja són malalts per usura, car si hun hom ve: «Per amor de Déu, prestau-me $\cdot X \cdot$ florins», «Plaume, mas seran $\cdot$ XII $\cdot »$, etc... Les CAMES e los PEUS que sostenen tot lo cors, són los llauradors, qui sostenen lo món, tots los stats, a reys, comtes, etc..., car de allò que ells treballen, tots ne havem a viure; mas ja són malalts, car ja no paguen delmes, e, si.u fan, no com deuen, juradors, envejosos, indevots. [S II 37, $21-38,21]$

Hi ha, doncs, la més mínima esperança que aquest cos -que representa el món sencer- pugui sobreviure? Tots els estaments estan greument tocats, però observeu que el major percentatge d'afeccions d'aquest cos ataquen òrgans associats a l'estament religiós, lato sensu: als cavallers correspon el cap; el ventre, als mercaders; les cames i els peus -que es podrien considerar equifuncionals--, als llauradors; però, als religiosos, els correponen les orelles -als confessors-, el nas - a les persones devotes en general- i la boca - als preveres-! I bona part de la malaltia té a veure, principalment, amb la gestió de les riqueses: la gran acusació és la simonia, l'avarícia, la malversació. He volgut subratllar en el text els termes que tenen a veure amb aquest camp semàntic, que predominen abasegadorament per damunt d'altres malalties subsidiàries —com ara la hipocresia o la falta de devoció-.

Però, de fet, és Ferrer mateix qui subratlla aquesta realitat amb un altre text de gran contundència, que prenem de l'esmentada antologia de Chabás:

Amichs eren de Déu els primer[s] christians per la sancta vida que fahien; principat es aço dels religiosos, qui són princeps de doctrines, mas ara no son princeps per la mala vida que fan, que totalment son destroits. No han deguna per-

blen els més febles són els més necessaris [...] Per això, quan un membre sofreix, tots els altres sofreixen amb ell, i quan un membre és honorat, tots els altres s'alegren amb ell.» Cito segons la $B i$ blia Catalana Interconfessional. 
feccio, que TOTS LOS STAMENTS CHRISTIANS SON DESFALLITS. Si VOLEU ANAR ALS ECCLESIÀSTICHS, TOTS SON SYMONIATICHS. En la prelatura, dignitat e rectoria no y entre degu per la porta. La porta es ésta: ne ab desig, ne engins, dons, servicis; mas per inspiració divinal o elecció verdadera: hi deuen entrar per la porta, mas ara per lo postigo. Ladres, ladres son. E puix, quan hi son entrats, velvos plens de ufanies, avaricia, luxuria. ANAuvos EN REligiosos. TOTS SON LOGRERS, dar diners a juheus a logrejar, propietaris, avariciosos ¿E DE CASTEDAT? POCHS SON QUE NO HAJEN UNA SPECIAL, QUE NO VULLEN HAVER UNA FILLA. ¿LES CEREMONIES ON SON? ¿E LOS DIJUNIS? N'el tall de la vestidura: tot ne va en banda. Si vos anau als CAPELLANS, son jugadors de daus, taffurs, bagassors, juradors, bevedors per tavernes, ajustadors de diners. Si parlam de CAVALLERS, que deuen fer sostenir la cosa pública, vídues, etc., e ara ¿què fan? Cremen esglesies e roben e desfan comunitats, matar homens. Si es una vidua jove, o fadrina pobre, trameten hi alcavotes a les serventes de la casa, hoc a les dides, may cessen fins que les han haúdes. Avant si anau a CIUTADANS, totes les rendes son logres, ab les quals vihuen coma porchs, ben menjar, beure, dormir e darse plaers carnals. Si anau a MERCADERS, venent e comprant tot es frau e logre, e pijor logre sobre logre. Dirán, no tinch diners, etc. Mes si anau als LAURADORS, los uns se enganen als altres. Si n'hi ha hu simple tots lo destroexen, e ja no paguen be los delmes. Les DONES axi com a cans fan lo matrimoni. A les primeres parauletes no han cura de la ordenació de la Esglesia [...]. [Chabàs 1995: 318-319]

Exactament com comentava Caro Baroja, més amunt, heus ací un religiós blasmant la realitat en què li ha tocat de viure. I vet ací que, en aquest escarafall de crítica, no s'està de bescantar els religiosos: no cal, potser, l'al·legoria del cos místic, perquè els seus mots ja són prou explícits. Si bandegem ara els aspectes econòmics de la seva crítica incendiària, ${ }^{16}$ trobarem que les faltes enumerades cobreixen també la major part dels aspectes de la vida, estament a estament: té el mateix caràcter totalitzador d'una obra com ara el Recull d'exemples (=Recull), traducció catalana de l'Alphabetum narrationum d'Arnau de Lieja, compilació d'exempla pensada, en principi, ad usum praedicatorum. ${ }^{17}$

${ }^{16}$ L'anàlisi dels aspectes socieconòmics de la destructora crítica ferreriana és força complexa i no cap en aquestes línies. Per a una visió àmplia i detallada del que pensaven els moralistes sobre els professionals dels diners, recomano les interessants pàgines de R. J. Puchades (1999: 85-148) i l'estudi de M. Llop (1995). D'altra, banda també pot ser útil la lectura de les pàgines que dedico a la descripció dels mercaders i dels usurers en la introducció a la meva edició del Recull, veg. Arnau de Lieja (2004: I, 85-93). Finalment, cal dir que, durant la transició del segle XIV al Xv, pren rellevància, al si de l'església, el conflicte entre la visió tradicionalment positiva de la pobresa i la moderna lloança i defensa de la riquesa, dissensió i polèmica reflectida també en la prediació popular, com estudia àmpliament Mullet (1990: 126-173), on cita, a més, abundant bibliografia.

17 Agafem aquest punt de comparança —-l Recull—, perquè l'esquema de la seva bastida ens és especialment útil, però una obra com el Libro rimado de Palaçio, de Pero López de Ayala —que esmentaré més avall — no és més que — — en bona mesura - l'hàbil i reeixida -literàriament parlant - posada en vers d'una reflexió moral sobre el món, punyent i dura, en molts aspectes perfectament parangonable a l'habitual dels predicadors. Així, per exemple, les estrofes 193-233, desenvolupen una crítica al clergat que, en realitat, és una mena d'amplificació del que s'afirma en la 191: «Está el mundo en quexa e en tribulaçión: / los nuestros regidores son dello ocasión; / e así 
Arnau de Lieja, en veure's obligat a organitzar el maremàgnum d'exempla que arreplega perquè hom en pugui treure profit fàcilment, elabora un índex temàtic - mantingut en llatí en la versió catalana - que ens permet copsar quines eren les facetes catalogables de la vida, aquelles sobre les quals era previsible el combat dialèctic del sermó. Aquest índex ens mostra, doncs, un autèntic mapa de la vida mirada amb ulls de predicador. I aquest mapa ens ensenya quins poden ser els punts febles - les possibles fonts de desviacions i pecat- del públic per al qual ha estat dissenyat. Entre altres coses ens serveix per a veure que existia tot un ben assortit rebost de tòpics preparats de bestreta per a ser utilitzats sobre els més diversos aspectes de la vida: sobre el capteniment dels advocats i dels jutges, o dels mercaders, de la dona, sobre la blasfèmia, sobre el pecat de la luxúria... així com sobre les més variades facetes de la vida dels religiosos.

Sobre aquests últims, per exemple, els mots-clau sota els quals hom encabeix la matèria narrativa seleccionada són abbas, clericus, monachus/monialis, predicator, prelatus, sacerdos, religiosus. Cadascun d'aquests mots-guia es desplega en una elaboradíssima xarxa de possibles accions: abbas discretus peccatores a peccatis retrahit, abbas bona monasterii non debet amicus carnalibus dare, predicator discrete debet predicare secundum condiciones audiencium, sacerdos pro mortuo frequenter debet celebrare, religiosus non debet excedere in potu. Molts exempla d'aquest repertori - i molts temes de l'índex que he resumit ací-, pensats en principi per a la correcció de costums, podien ser autèntics bumerangs dialèctics en la mesura en què podien ser llavor esponerosa si hom els volia usar contra els seus propis creadors. Lògicament, si un tema diu "Predicator ea quae predicat debet facere» (núm. 565), implícitament denuncia l'existència de predicadors hipòcrites i falsaris, cosa que podia posar oli al fanal de qualsevol que cerqués un motiu més de sàtira anticlerical, tant més que el primer acusador contra, diguem-ne, clergues falsaris havia estat el mateix Jesucrist, que qualificà els fariseus d'hipòcrites i de sepulcres $\mathrm{em}$ blanquinats (cf. Mt 15, 7, per exemple, i molt especialment Mt 23, 1-36). No endebades, l'exemplum que, amb el núm. 714, clou el Recull tracta el tema de la hipocresia i narra el fet que un monjo, al punt de la mort, crida els seus companys, els quals hi acuden «cuydant-se que abans que-s morís los digés algunes coses de devosió, e santes e plesentes a las ànimes». Tanmateix, es troben la sorpresa que el moribund els declara que ha estat un perfecte hipòcrita «Sapiats que jo no fui tal con vosaltres vos pensats. Quant me vèieu degunar, sapiats que amagadament mengava», per la qual cosa, com a càstig, li ha aparegut un drac infernal que se l'engul de mica en mica i, segons narra, «En la sua coa tinc meses las mias cuxas y las quames ligades, $y$ los peus. E tinch lo seu cap dins la mia boqua, qui-m sorbex la ànima e ja le'm trau del quos».

cresçen los males — además muchos son—, / ca cobdiçia les çiega todo su coraçón». A partir d'ací descabdella una crítica que comença ni més ni menys que pel bisbe de Roma - «que papa es llamado» (est. 193) - i passa per tot l'etament religiós, tot prenent alguns dels tòpics que ja hem vist adesiara: l'avarícia (est. 219), el concubinat (ests. 225, 227, 228), el desconeixement dels ritus més bàsics (est. 226), la simonia (est. 229) —que sintetitza en quatre versos el contingut de l'evangeli paròdic vist més amunt: «[...] quien les [es refereix als cardenals] presenta copas buenas o sus señales, / recabda obispados e otras cosas tales»-, etc. 
Final terrible, cal reconèixer-ho, per a castigar un dels pecats que més se sol denunciar en relació a l'estament religiós: el de la hipocresia, que va practicar el moribund fent creure que acomplia l'abstinència pròpia de la regla. L'abstinència i la seva complicada casuística apareix força decorada al Recull: la seva pràctica era difícil, car era possible infringir-la tant per excés de rigor -cosa que posava en perill la salut i afavoria el subtil pecat de l'orgull, un de les amenaces més temibles a la virtut més provada- com per defecte.

Cal tenir en compte, d'altra banda, que el pecat de la gola - la contrapartida de l'abstinència - podia tenir efectes secundaris molt greus. En el Libro rimado de palaçio ens adverteix Pero López de Ayala, a qui ja hem recorregut més amunt, que, si volem evitar pecar contra el sisè manament «atienpra tu comer, non sea desigual» (núm. 48); i, en tractar de la luxúria, ens adverteix «D'esta son ocasión el mucho conversar / sienpre con las mugeres e non se bien tenprar / en comer e en bever, e oçioso estar: / por ende de todo nos conviene bien guardar» (núm. 92).

El motiu d'aquesta prevenció contra a gola és perquè l'excés en el menjar - $\mathrm{i}$ en el beure que l'acompanyava - podia ser el pas previ a un pecat infinitament pitjor: el de la carn, el de la luxúria. Bé ens ho explica, precisament, un nou exemplum del Recull, si bé la falta que se'n deriva és de rang menor entre les relacionades amb la luxúria:

[299] MIRACLE E EXIMPLI DE UN MONGE QUI FURTADAMENT MENJÀ UN BUNYOL

Gula aliquando in peccatum carnis hominem inducit. Petrus Damianus.

Segons que recompte Pere Damià, un monge una vegada portave buyols al monestir e, havent temptació del peccat de gola, menjà un bunyol furtadement. $\mathrm{E}$, tentost que l'ach menjat, ach ten gran temptació de lla luxúria e entengué's ten fortment en aquell pecat que féu polució molt desordonade, car tentost que ach menjat lo bunyol li entrà Satanàs en lo ventre.

Però, si ens queda algun dubte al respecte, bé podem recórrer a la lectura dels capítols 301 i 315 del llibre tercer de Lo crestià, de Francesc Eiximenis (1984: 136-141) ${ }^{18}$ És ací on trobarem que l'immoderatus appetitus edendi-que és com defineix Hugo de Sant Víctor la gola- abraça l'excés de beure (ibid.p. 136) i esdevé quasi una mena de déu per a l'home golós, ja que aquest viu «amb la gola sobre totes coses» (ibid.), amb la qual cosa es capté com un idòlatra ni més ni menys que del seu propi cos - «de lo ventregaç, que és sac plen de fems, e latrina en què tot lo cors gita ses immundícies» (ibid. pp. 136-137)-, fet especialment condemnable si tenim en compte que «lo nostre cors sia temple de lo sant esperit». Més encara, el golós oblida fins a tal extrem Déu, que prescindeix de beneir el seu menjar i d'agrair-li'l en acabar-lo, per la qual cosa «lo diable los

${ }^{18}$ És molt recomanable llegir, alhora, els comentaris de Rubio (2004: 6-9), qui resumeix de manera admirablement clara el bessó dels raonaments eximenians al voltant del tema que ens ocupa ací. 
entre en lo cors ab lo menjar, per la gran irreverència e desconeixença que fan a nostre senyor Déu» (ibid. p. 137), ${ }^{19}$ cosa que pot ben bé certificar-nos el monjo protagonista de l'exemplum suara citat. D'altra banda, l'home ha de respectar la seva pròpia naturalesa i ser conscient dels mals que poden venir-li precisament d'aquest pecat, que és capaç de privar-lo de seny i fer-lo, doncs, actuar com una bèstia (ibid. p. 137). Comptat i debatut: l'abstinència controla directament l'apetit $i$ indirectament tot el cos: el refrena tot mantenint l'home en la seva racionalitat. $^{20}$

Fins ací, com s'ha vist, el que he ofert és una petitíssim panorama de la crítica vers l'església en boca d'autors —o en pàgines d'obres - pertanyents a l'església mateixa. Es tracta, doncs, de la crítica de qui té una palesa voluntat de reforma. Però, com és lògic, en la mesura en què l'estament religiós aspirava a un altíssim grau de perfecció espiritual i maldava per exercir un control exhaustiu sobre els seus fidels, es posava en el punt de mira de la sàtira d'uns homes que vivien la vida d'una altra manera, que sovint no entenien el perquè del rebuig de les energies i instints més bàsics de les persones i que, a més, s'adonaven de la crua realitat que s'amagava al darrere de determinats religiosos, estesa o excepcional, però, en qualsevol cas, molt allunyada d'un capteniment considerable com a meritiori. I és que, amb algunes matisacions, es pot donar per bona l'afirmació de Moll (Poggio 1978: 16) en el sentit que la narrativa medieval, excepció feta de l'hagiogràfica, «es distingeix pel seu anticlericalisme, i més que res per la denúncia de la immoralitat clerical en matèria de sexe».

El panorama que sorgeix d'aquest distanciament irònic ens el resumeix -i n'és només un cas - un autor espanyol com Hernán López de Yanguas (1487?1550?), que escriu un Triumpho de los religiosos (Martínez 1997: 100-104) on articula, en cobles de dotze versos octosíl-labs, tota una crítica i censura dels costums dels clergues, els quals - afirma - «se podrían bien llamar santos / si idiotas es santos ser» (ibid. p. 100). Primerament en ridiculitza els cants: «Otros con bozes grosseras / y psalmos mal entendidos, / presumen más que de veras / que deleytan los oydos / de las supernas esferas». Entre altres trets subratlla la hipocresia i l'orgull. De la primera en diu: «Ay alguno que se estima / de religioso en la gana / viste cilicio por cima / y junto al cuerpo trae lana / porque menos le lastima» (ibid. pp. 101-102); del segon: «En secreto te revelo/de los que a mí se me offrecen / que piensan que es poco el cielo / para lo que ellos merescen / aunque tienen con mí el zelo. / Bien sé yo quién se alabó / que siempre peces comió / otro contó mil millones / de ayunos y devociones / que con açotes passó / otro no sé qué visiones / que el ángel re reveló» (ibid. 103).

${ }^{19}$ Precisament, sota el tema «Benedicendus est potus et cibus antequam sumatur», Arnau de Lieja ens narra (Recull núm. 89) el cas de la monja en la qual entrà el dimoni perquè es va menjar una lletuga de l'hort «sens que no la senyà ne la beney», com molt bé explica el diable quan, comminat per un home sant a abandonar-la, fa: «-No n'eixiré, car jo no aní a ella, ans vench ella a mi, car jo m'estave en aquella letuga e ella mordé'm».

${ }^{20}$ Per no estendre'm més, remeto el lector a Amau de Lieja (2004: I, 97-105), on trobarà el que el Recull ens diu sobre el tema de les culpes i les expiacions, així com alguns textos paral-lels al voltant d'algunes virtuts i pecats. Pel que fa a l'abstinència, veg. ibid. pp. 98-99 i 103-104. 
Però si així és com bescanta un poeta culte els ordes religiosos en general, la veu popular sol centrar-se amb especial delectació en l'aspecte eròtic de la vida del clergat, tractat sempre de manera punyent, directa i sense embuts, amb afany ridiculitzador. Bona mostra en podem trobar en el deliciós llibre que Janer (reed. 2003) consagra al cançoner eròtic mallorquí, on hi ha tot un capítol dedicat a, en paraules de l'editor, «gent d'església» (Janer 2003: 111-119), on podem trobar una tipologia bastant variada d'activitats sexuals protagonitzades per religiosos i beates. Per exemple, se'ns parla de capellans avesats a masturbar-se: «Es capellà Micolau / cada dia el se remena / i el senten tots com alena / des de la Torre d'en Pau» (ibid. p. 113b); «iHeu conegut el fra Pere? / Avorrit de tots es sants, / se feia amb ses dues mans / sa pell de sa fava enrere» (ibid. p. 115b). O se'ns descriu la hiperactivitat sexual d'alguns religiosos: «Es capellà Micolau / sempre du ses calces brutes / i de tant d'anar de putes / te es cap de sa fava blau» (ibid. p. 113b); «Es rector de s'Arracó / no vol dir missa primera, / perquè té més barrinera / que un gall de possessió» (ibid. p. 115a); «Darrera una mata bona, / vaig sentir lladrar un ca, / i va esser un capellà / que barrinava una dona» (ibid. p. 112a). O denuncien alguna de les tàctiques de seducció dels religiosos, com ara atreure's els infants per tal de tenir més a l'abast llurs mares: «Diuen 'es frares', 'es frares', / i jo dic 'es capellans'; fan joquets an ets infants / per tenir bo amb ses mares» (ibid. p. 112b); «Mon pare, quan vós no hi sou / a ca-nostra hi ve un frare; / a mi me dóna confits / i besades a mumare» (ibid. p. 116a). I sembla que una de les consequiències de tot plegat és que quasi tothom es pugui considerar fill de capellans o frares: «Si sou canonge o frare / o rector o capellà, / mem, escoltau, bon germà: / donau-me sa mà a besar / que p'entura sou mon pare; / vàreu enganar mumare / en lo seu fadrinejar» (ibid. p. 118a). De fet, ni la reina se n'escapa, d'aital amenaça: «La reina estava emprenyada / i no sabia de qui. / Va esser un frare caputxí /que l'havia barrinada» (ibid. p. 115b). ${ }^{21}$

Aquesta vena complagudament bròfega la tenim a l'abast també en castellà — després d'una llarga tasca de reivindicació i recuperació-. D'una banda, hi trobarem moltes cançonetes que descriuen els capellans -més que no pas els frares- com sexualment superdotats: ${ }^{22}$ «Al cura de Villarejo / de Salvanés / le llegan los cojones / hasta los pies» (p. 117); «Los cojones del cura / de Villalpando / los llevan cuatro bueyes / y van sudando» (p. 117); «Los cojones del cura / de San Segundo / que no los hay iguales / en todo el mundo» (p. 156); «Los cojones del cura / de Cogollor, / dicen que en toda España / nada hay mejor» (p. 156). D'altra banda, el capellà és vist sempre com una amenaça, per ser un possible competidor o intrús sexual: «Con los curas a obscuras / nunca te quedes; / que aunque se ponen faldas, / no son mujeres» (p. 98); «Háganle la cama / en el patio al padre, / que, aunque sea pariente, / basta ser fraile» (p. 98). Finalment, hi ha innombrables cantars que narren les proeses sexuals dels capellans: «El cura de mi lugar / lleva la sotana rota, / se la rompió en un zarzal / por ir detrás de una moza» (p. 156); «El cura vendió la burra / para no darle cebada, / y ahora tiene que ir / a caballo en la criada» (p. 156); «Entre un cura de

${ }^{21}$ Per a una descripció general del caràcter anticlerical d'aquestes composicions i d'altres mostres de literatura popular, veg. Janer (2003: 51-54) i (1982: 13-15, 115, 120-126).

22 Citaré segons Urbano (1999), tot indicant el número de pàgina entre parèntesis. 
Palencia / y otro cura de Zamora / se jugaron a la brinca / el coño de la Leonora».2?

\section{Tòpics anticlericals convertits en literatura de pur esbarjo: el cas del Llibre de fra Bernat}

No em dedicaré ara a descriure les claus de la mentalitat carnavalesca i de la seva capacitat d'inversió i subversió, ${ }^{24}$ perquè implicaria estendre'm innecessàriament. De tota la inexhaurible deu d'humor irreverent i irreligiós m'interessa, ara i ací, concentrar-me només en un clixé: el prototipus que representa el religiós que actua, amb més o menys cinisme, en contra d'allò que seria, en principi, esperable des de la perspectiva de la moral establerta que ell mateix, teòricament, defensa. Tinguem en compte que, com és lògic, la contraimatge d'un professional de la virtut és la d'un pou de vicis i, per extensió, la del perfecte hipòcrita. Ara bé, si tenim en compte que el tret per excel-lència més cridaner de qualsevol religiós és el celibat, entendrem que aquest sigui el primer que salti pels aires en qualsevol sàtira anticlerical: anticlericalisme i expansionisme eròtic solen anar de bracet, encara que no sigui l'única combinació possible. ${ }^{25}$

${ }^{23}$ No és lloc ni moment per a aprofundir en aquest tema, però va existir la tendència, força documentada, de reservar el paper bròfec i obscè a religiosos i capellans en obres de la més diversa mena. Així, per exemple, Nicolás Fernández de Moratín, en el seu Arte de la putas (1999: 52-55), atribueix a un frare la invenció del preservatiu — «[...] que de un fraile / sólo, o del diablo, ser invención pudo» (p. 53, vv. 143-144)-- Val la pena extreure'n alguns fragments, com ara la descripció del frare: «Iba el reverendísimo cornudo / ardiente, como siempre están los Padres, / por el arroyo Abroñigal al campo / una tarde de sol del mes de Enero, / y en un barranco se encontró hecha un cuero // una de esas grandísimas bribonas / que piden dinero arremangadas» (p. 53, vv. 145152). Quan el frare s'hi prepara ——upresentando un mangual como una torre» (p. 53, v. 160)-, descobreix que el sexe de la dona és «[...] podrido, / lleno de incordios, unos reventados, / otros por madurar, otros maduros, / sobresaliendo el clítoris llagado / sin un labio y pelado a repelones; [...]» (pp. 53-54, vv. 162-166), davant la qual circumstància, el frare - «desvirgador mayor de su colegio» (p. 54, 183) - es va llevar «de la cabeza astuto la capilla [...] y calando a modo de sombrero / en su bendito miembro la capilla, // así lo mete. [...]» (pp. 54-55, 186-195).

${ }^{24}$ És ben conegut el treball ja clàssic de Bachtin (Bajtin 1987) sobre la cultura popular, brillant estudi de la seva capacitat subversora mitjançant el riure, aspecte igualment central en l'assaig, ja esmentat, de Hauf (2000). També és interessant l'aportació de Gaignebet (1984) sobre el camaval a partir de l'estudi comparativista del folklor. La bibliografia sobre la festa popular a l'Edat Mitjana és enorme. Com a panorama introductori, pot ser útil l'interessant llibre de Ladero (2004), on es repassa el calendari festiu medieval - general, no pas sols popular - amb constants remissions a l'àmbit hispànic, particularment castellà. Per a l'àmbit català, veg. Prat+Contreras (1984).

${ }^{25}$ Sense cap pretensió d'exhaustivitat, i només per orientar el lector que pugui tenir interès a conèixer aquesta mena de textos, remeto a la següent bibliografia mínima, en la qual, efectivament, hom trobarà obres d'interès purament eròtic, però sense matisos anticlericals, alhora que textos clarament anticlericals - com a demostració del que he afirmat suara-: Les famoses facècies de Poggio són a l'abast Poggio (1978), traduïdes al català per Francesc de B. Moll, que les edita precedides d'un breu però interessant pròleg. La literatura eròtica i satírica catalana de finals del s. XV es pot gaudir en Fenollar+Gassull et al. (1988), editades V. Pitarch i LI. Gimeno, amb introducció de S. Jàfer, edició que, de fet, equival al segon volum de la de Pitarch+Gimeno (1982). Com a proIongació cronològica d'aquesta mena de textos és important l'estudi i edició d'A. Rossich (1989). 
Recordem el cas de l'aventura de fra Juliot, que narra l'Ase turmedià: el savi quadrúpede intenta anul-lar l'argument que havia emprat fra Anselm en el sentit que l'home és superior als animals per tal com «tenim ordres, religions i convents de cordellers, framenors, jacobites, frares predicadors [...] en els quals hi ha molts sants homes, menant santa $i$ honesta vida, i els quals, per a servir a Déu, han deixat i abandonat tots els plaers mundanals, vivint castament; i mai no prenen mullers: i esquiven els pecats, principalment els set pecats mortals» (Turmeda 1928: 109-110). L'Ase bombardeja aquestes afirmacions una a una. Demostra, amb exempla, que els religiosos cauen en tots els pecats mortals; però el primer de tots és el trencament de la castedat. Narra, llavors, el cas de fra Joan Juliot (Turmeda 1928: 113-119), que s'aprofita de la ingenuitat de madona Tecla fent-li creure que li ha de pagar el delme de les relacions que mantingui amb el seu home: de cada deu, una, ha de ser amb ell. Li fa un càlcul ràpid i generós, amb rebaixa inclosa, del deute acumulat i procedeix a cobrar-se'n la primera tongada d'immediat. ${ }^{26}$

El confessor, precisament pel coneixement privilegiat de les intimitats dels penitents, és fâcilment protagonista de situacions escabroses. El fet és recollit fins i tot en compilacions d'exempla adreçades a predicadors, com ara el, ja citat, Recull d'exemples d'Arnoldus Leodiensis. L'exemplum número 152 d'aquesta obra ens conta el cas del confessor que, excitat pels pecats d'una penitent, li proposa «que-s gitàs ab ell carnalment». Ella no accepta, per la qual cosa el confessor, ofês, dóna a conèixer públicament els pecats de la dona. L'exemplum 153 del mateix repertori conta el cas d'un confessor indiscret que, a força de preguntes inadequades, desperta la lascívia d'una monja. ${ }^{27}$

Ben mirat, el motiu central d'Els planys del cavaller Mataró és, precisament, la mala jugada d'un confessor. El cavaller Mataró, de colp i volta, se sent desatès per la seva estimada. Envia una mitjancera perquè intenti descobrir-ne la

Com a complement a tot plegat, és important la lectura del repertori lexicogràfic preparat per $P$. Vila (1987) — per a la part medieval i renaixentista— i (1990) - per als segles XVIII-XX_-, dos volums precedits per sengles detallats estudis introductoris. Les referències bàsiques pel que fa al castellà ja les he incloses més amunt.

${ }^{26}$ Es tracta pràcticament de la mateixa història que trobem en la facècia núm. 155 de Poggio (1978: 117), si bé ací el confessor no se'n surt del tot, car, el marit de la seva penitent, assabentat del fet, el convida a un sopar amb família i amics, durant el qual esventa la seva mala jugada i afirma: «Ja que et toca cobrar deume de totes les coses de la meva dona, també en cobraràs d'això». Li posa al davant un vas «ple d'excrements i orina de la dona» i l'obliga a beure-se'l.

27 Vila (1990: 8-11) en el pròleg del seu Bocavulvari inclou una referència a un interrogatori passat per la Inquisició al canonge Pedro José Molinas. En un dels seus punts es pot llegir que «este mismo confesor dijo a la misma penitenta en una de las confesiones referidas que se podía pecar por uno y otro de los agujeros que tienen las mujeres, lo que ignoraba la penitenta.» En el paràgraf immediatament anterior es llegeix: «preguntó a la misma penitenta si en el siglo siendo niña habia pecado con hombres, si se lo habian metido muy adentro, si le habian hecho mal, y si le habian escupido en las partes nombrándolas con la palabra mallorquina 'foradell'., Veg. també R. Roselló + J. Bover (1992: 111-137), on es recullen una gran quantitat de casos de confessors sol-licitants del s. XVI al XIX. 
raó. Aleshores s'assabenta que ha entrat en acció un confessor. ${ }^{28}$ Aquest, fent el seu ofici, pregunta directament a la penitent per la seva relació amb el cavaller Mataró. Ella li la descriu en termes cortesos, ja que arriba a declarar que (Pacheco 1983: 211) «per mi ell ha faits mants mots / perquè eu li'n port mais d'amor, / car ell me dóna gran lausor / aitant com pot en sos xantars, / e açò saben los joglars / qui van sovint per cort xantant.» Davant això, el confessor comença a bescantar el cavaller (Pacheco 1983: 212): «Ara entendets bé ço que us dic: / que tots los fills de cavallers / tots són truxés e ufaners, / plens d'enveja e malvestat, / complits d'ergull e de pecat / e de tots mals ensenyaments [...]». La difamació s'allarga encara molt i intenta sempre obrir-li els ulls i fer-li veure que, continuar amb el cavaller, perjudica el seu honor. A partir d'ací, comença a criticar el capteniment de la dama, especialment que es converteixi en motiu de pecat quan ix al finestral tota endiumenjada per a mostrar-se al seu amant: ${ }^{29}$ «Aicells qui us vesen així estar / en vostres finestrals pintades / faent-los semblants e ullades, / per força los covén gardar, / car vosaltres los faits errar / ab vostre malvat continent, / e aicells qui han pauc de seny / fet-los anar lo cap engir, / no em meravell si els fets fallir» (Pacheco 1983: 213). Per què no se'n meravella? Doncs perquè ell mateix se sent captivat per la bellesa de la penitent $i$, de fet, prova sort amb atac directe: «car jur-vos per l'hàbit que port / que si vós volíets fort / tant me proíets far e dir / que l'orde em faríets jaquir / e faria el vostre voler, / e si us venia a plaser / que volguéssets sofrir de mé / que eu fos a la vostra mercè, / bé hi hauria gran gasany fait, / car lo cor m'havets del cors trait / sol depuis que só prés de vós, / tant vos vei lo cors graciós, / los ulls amorosos e rients, / la boca fresca e belles dents, / los cabells saurs, albits e grans.» I tot seguit d'aquesta apassionada descripció de la penitent, encara rebla el clau: «No em cal pus dir, car en tot cars / vos vull servir trop mai que déu, / e si no m'acorrets en breu, / pus m'havets del senys fet eixir, / a greu mort me farets morir, / e vós no hi gasanyareu re; / e provar-vos he per ma fe / que val més de mi que d'altrui». A partir d'aquest moment, explica quins avantatges fan millor una relació amb ell que no pas amb un cavaller (Pacheco 1983: 214). Al-ludeix, al seu propi favor, una major facilitat per a ser discret tant perquè el seu ofici li permetrà visitar-la d'amagat com perquè no comparteix el costum dels cavallers de fatxendejar de les victòries en el camp de l'amor - «hic vendrai tot cobertament, / et ab tant la malvada gent / no n'haurà degú mal pensar, / car mil tants serà pus celat / de mi que d'altre poria ésser»-. Subratlla que, malgrtat la descurança dels seu hàbit fraresc, «eu hai lo cor pus escalfat / que d'altres qui van pus polits; / e sabrai far vostres delits / així com a vós pertany de far». Al cinisme més es-

${ }^{28}$ De fet, és el cavaller mateix el narrador de la seva pròpia història. Des el començament ens diu, sense embuts de cap mena: «e és-me vengut aicest mal / tot per un mal confessor / qui meten les gents en error / ab semblant de dar bon consell / e són coberts de falsa pell, / perquè hom no es pot d'ells gardar [...]» (Pacheco 1983: 203).

${ }^{29}$ No m'estendré ací intentant decorar la visió que la literatura moral i religiosa donava del sexe femení. Remeto, en aquest sentit, a l'epígraf dedicat al cos, el sexe i les dones en el context de la literatura exemplar dins el meu pròleg a Amau de Lieja (2004: 64-79) i a la bibliografia que s'hi cita. $\mathrm{Val}$ a dir que molts dels tòpics de la misogínia medieval són articulats ràpidament per aquest confessor desvergonyit: per exemple, la crítica a l'excés de luxe i ornamentació o al fet que la protagonista sigui finestrera - s'agradi de mostrar-se per finestres, balcons, finestrals, etc.-. 
tupend hom hi arriba quan el frare comenta un avantatge que li és del tot privatiu: «Doncs de pecat no us cla témer / pus faita hajats confessió, / que eu vos farai l'absolució / aital con vós sol la volets, / que aital poder n'hai, ja ho sabets, / con negun altre confessor.» $\mathrm{Cal}$ reconèixer que s'ho ha ginyat molt bé: amb ell pot pecar, però d'ell pot rebre, tot seguit, el perdó, cosa impossible amb el cavaller.

La penitent respon amb violenta indignació en veure l'actitud del frare i li amolla que mai no havia trobat «que en semblança de sanctidat / null hom tan cruelment pecàs.» L'acusa, doncs, d'hipocresia i immoralitat, però el frare, que la sap ben llarga, té l'excusa perfecta (Pacheco 1983: 215): «Ma filla cara, no us desplaia / trestot açò que us hai dit, / car ja Déus no em saul l'esperit / si ho hai fait mas per assajar / e que us hai volguda provar / si havets de senys compliment.» Tot, doncs, havia estat una pura ficció per provar la virtut de la dama: aquesta venç i el frarot se'n fingeix satisfet, i la lloa dient-li que és «senes par».

Ara bé, si no pot ser d'ell, que no sigui de ningú, sembla pensar el confessor, perquè després del rebuig de la dama li improvisa un sermó que, de fet, ja havia tingut el seu efecte quan es produeix l'entrevista entre l'estimada del cavaller i la mitjancera tramesa per aquest. El confessor l'anima que «vullats fer ço que us dirai»: li prohibeix portar roba entallada, amb ornaments d'or ni perles, li demana que vesteixi amb senzillesa i que porti vel; insisteix molt «que no us façats al finestral, / car no hi podets fer sinó mal, / que avinentesa és de pecar.» Vet ací el motiu pel qual el cavaller no la hi havia tornat a veure i també la raó per què la mitjancera s'havia sorprés en trobar-la canviada (Pacheco 1983: 208): «Don sapiats primeraments / que en son cap tingué un vel, / no creats que fos així bel, / ans fo honestament lligada / e fo d'una saia morada / sens nulles obres gint vestida / [...] / E estec simple e humil, / senes que no es moc de parlar. / E eu qui així la vi estar / ja ho tinguí a mal senyal [...]». Efectivament, les intencions del confessor havien quedat insatisfetes, però el seu sermó sí que havia tingut èxit. La mitjancera, però, intenta obrir-li els ulls amb versos també contundents (Pacheco 1983: 218): «car no es fraire ne preveire / qui mai volgués bé per altrui; e podet-ho veser en lui, /que, faent la confessió, / ab tota ferma intenció / mès son poder en vos trair, / e si el volguéssets fer jausir / del vostre gentil cors assaut, / ell ne fóra jausent e baut / e ho prenguera tost e de grat; / mas Déus vos ha tant de seny dat / que us sabés guardar de follor. / Perquè us dic que aital confessor / no deu ésser cregut de res / [...] / e quan viu que alre no hi poc far, / hac son voler e son mal pens / que aquell mesquí vos acusàs / qui met son temps en vós servir.» No hi té èxit, però, la mitjancera. El mal ja està fet i l'obra acaba amb una dolguda lamentació adreçada contra els mals confessors que, en paraules de la mitjancera, fan «als fins aimants pits de mort» (Pacheco 1983: 220)..$^{30}$

${ }^{30}$ De tota manera, la hipocresia en fet de moral sexual és només un aspecte d'una hipocresia major, més àmplia, que vindria a ser com una marca general d'aquest estament en aquesta mena de textos. Llegint el que es diu en el Sermó del Bisbetó sobre capellans i frares (Pacheco 1983: 180182) veurem com la hipocresia també abraça aspectes econòmics i socials: «Dels capellans diré un petit [...] / Alguns ne són, e jo ho sé bé / que en tots llurs gests / se mostren bons e honests, / e si els 
En el fons, el que s'està articulant ací és una versió satírica i molt hàbilment desenvolupada - pel que fa a l'ús dels narradors i al ritme discursiu - del vell tema de la superioritat de l'amor del cavaller o del clergue, de vella nissaga medieval. Recordem, per exemple, la diatriba entre Elena —enamorada d'un cavaller - i Maria — estimada d'un clergue - conservada fragmentàriament en un text lleonès de finals del segle XIII (Alvar 1985: 159-177). Pel que ens n'ha arribat, no es tracta d'un text satíric, sinó d'un simple contrast d'opinions sobre els avantages o desavantatges de relacionar-se amb un o altre tipus d'amant. ${ }^{31}$ Sí és cert, però, que la literatura de debats tingué presència fins a finals de l'Edat Mitjana i que, precisament, van existir debats de caire satíric. ${ }^{32}$ No oblidem que just textos com Lo procés de les olives - on es debat la potència sexual dels joves i dels vells - o Lo somni de Joan Joan - text íntimament imbricat amb l'anterior- pertanyen també al gènere del debat i es caracteritzen per un to més o menys satíric, d'una banda, i per una intel-ligent i molt elaborada estructura. ${ }^{33}$

tocau / a llur honor, o els comanau / fets de diners, / giren-se tost de l'envers / e es mostren altres: / d'aquests direm entre nosaltres / los del coll tort.» /// Dels frares: «d'uns jovencells hic trobareu / qui es mostren sants, / e fora els murs són fins bergants / e mundanals. [...] En tots llurs fets / encara, si us n'entremetets, veurets pus fort / que molts treballen fins a la mort / perquè s'avancen / e ab maneres e amistances / ab grans senyors, / perquè els prenguen per confessors [...]». Tot i així, també cal dir que la major part del Sermó del bisbetó es consagra a satiritzar les dones, que agrupa segons un esquema molt semblant al mantingut en l'Spill de Jaume Roig: Viudes, monges, beates, precedides d'una part general, on es plantegen els grans tòpics de la literatura misògina.

${ }^{31}$ Així, per exemple, Elena afirma (Alvar 1985: 168) - cito corregint-ne alguns aspectes de la transcripció-: «Creas me de cierto, / que mas val un beso de infançón / que çinco de abadón, / como el tu barvirrapado / que siempre anda en su capa en çerrado, / que la cabeça, e la barva e el pescueço / non semeja senon escueso. / Mas el cuydado mayor / que ha aquel tu señor / de su salterio rrezar, / e sus molaziellos ensenar; / la batalla faz con sus manos / quando bautiza sus afijados; / comer e gastar / e dormir e folgar, / fijas de omes bonos enartar, / casadas e por casar.» Vegeu, doncs, la mala opinió que l'estimada del cavaller té del clergue com a amant -i pareu esment, de passada, en l'acusació que el clergue s'agrada de seduir, enartar, filles de bons homes, tant casades com fadrines. Evidentment, Maria respon de manera simètrica, en contra del cavaller: «Maria rrespuso tan yrada, / esa vegada: 'Elena, calla, / ¿por qué dizes tal palabra? / Ca el tu amigo / a pos del mio / non val un mal figo. / Quando el es en palaçio / non es en tal espaçio, / oras tien algo, oras tien' nada, / que ayna falla ela soldada. [...]'». Com que no troben el desllorigador a la querella, els cal recórrer a un jutge - el rei Oriol---, però el poema resta interromput.

32 En aquest sentit pot ser molt útil l'antologia de Simó (1999), on el lector trobarà, a més del debat d'Elena i Maria tot just citat, una variada selecció bilingüe - llengua original/castellà-, que abraça des de la Disputa del alma y del cuerpo fins al curiós Pleito de los colores, tot passant per altres textos com ara la La disputació d'en Buc ab son Cavall o el procaç Débat du cul et du con. Vegeu també el comentari de Pacheco dins Via (1997: 132, i n. 5).

${ }^{33}$ No podem estudiar-la ací, però la lúcida anàlisi de Jàfer (Fenollar+Gassull et al. 1988: 7-73) permet copsar aquesta estructura molt justament i gaudir de la seva refinada construcció. Especialment remarcable és la valoració que fa aquest filòleg de l'ús de la ironia, la sàtira i la paròdia com a elements centrals en el joc en aquestes dues obres -i entre aquestes dues obres- Cal també subratllar com - en les interessants reflexions amb què clou el seu pròleg (Fenollar+Gassull et al. 1988: 67-68) - col-loca els satírics valencians de finals del XV en una línea d'evolució pancatalana que neix ja amb els trobadors i passa, precisament, per obres com les que tractem ací: La disputació d'en Buc ab son cavall, el Sermó del bisbetó, Els planys del cavaller Mataró o el Llibre de fra Bernat. 
L'obra, però, més elaborada de tot aquest nucli riallerament anticlerical i de sexualitat despreocupada és el Llibre de fra Bernat i vull referir-m'hi per a anar acabant ja aquesta invitació a la lectura d'una literatura massa sovint bandejada. $^{34}$

La divertida aventura de fra Bernat ha estat estudiada posant-la en relació amb el món dels fabliaux francesos, narracions eminentment còmiques - amb predomini d'un agosarat component eròtic- escrites en octosíllabs apariats. ${ }^{35} \mathrm{La}$ història és bastant senzilla: l'autor, Francesc de la Via, cavalcant per un bosc, es troba amb fra Bernat, amb qui inicia una conversació que de seguida descobreix els peculiars trets de caràcter d'aquest menoret: li conta, sense embuts, que només dejuna de nits, que pertany al monestir de Sant Belluguet, consagrat, segons sembla, a una activitat eminentment sexual, i que va de camí cap al monestir de Davall Jau, on espera trobar-se amb una bellíssima monja que li té el cor robat. L'autor, després d'una llarga discussió sobre la moralitat del capteniment del frare, l'hi acompanya per veure en què acaba tot aquest fet. L'autor mateix ha de reconèixer la bellesa de la monja quan la veu. El problema és que no ha captivat sols fra Bernat, sinó també un cavaller i un cononge. L'endemà tornen els tres enamorats a visitar la monja, que els rep amb la intenció de burlar-se de tots tres. Amb aquesta finalitat, ordeix un pla: cita tots tres a la nit a la mateixa hora i lloc, havent-los donat esperances per igual a cadascú. El conflicte majúscul que es prepara esclata, efectivament, tal com estava previst i tots resten burlats, bé que qui més rep és el dissortat fra Bernat i l'únic beneficiat, inesperadament, és qui, fins aleshores, s'havia mantingut com a espectador: l'autor.

Ara bé, aquest argument tan simple, l'única pretensió del qual és crear una sèrie de situacions equívoques que facin petar a riure, es desenvolupa mitjançant un ús molt encertat de mecanismes paròdics i irònics que convé descriure per tornar a fer palès al receptor actual allò que també ho era per al medieval -i, per tant, per a facilitar la recta intel-lecció del poema- ${ }^{36}$

${ }^{34}$ Per a una informació general sobre aquest autor, veg. Riquer (1983: vol. 11, 274-287) i el pròleg de Pacheco a la seva edició de les obres de Francesc de la Via (1997: 9-156). Per al Llibre de fra Bernat, Riquer (1983: vol. II, 284-287) i Francesc de la Via (1997: 125-137 [estudi], 309-391 [edició]).

${ }^{35}$ Les noves rimades catalanes —octosil-labs també apariats-, la forma més corrent de la nostra narrativa medieval en vers, teníen una variant, coneguda com a codolada - terme d'etimologia discutida-, que consistia en alternar els octosíl-labs amb tetrasíl-labs. Sembla que aquesta variant se solia lligar a un contingut més aviat satíric -com és el cas del Llibre de fra Bernat-. Ara bé, el que importa subratllar, amb Pacheco (1983: 8), és que «Les noves rimades i les codolades són un pont entre la literatura aristocràtica de les corts i les facècies i contes tradicionals de les classes populars.» Pacheco fa notar com, a partir de finals del s. XIV, en aquestes obres «s'endevina la presència del món burgès, $i$ aquesta presència representa l'aportació de nous temes i tècniques noves que fan d'aquestes obres un gènere singular i un possible antecedent de la novel-la moderna." El poema en noves rimades d'Els planys del cavaller Mataró, al qual ja hem al-ludit, ha estat molt positivament valorat per la seva hàbil estructura narratològica en una aportació d'Ottaiano (1993: 5 43) - que es fa eco d'alguns dels plantejaments de Pacheco-, fonamental per a l'estudi dels anomenats fabliaux catalans, als quals pertanyen els textos comentats ací.

36 Pacheco ha remarcat (Via 1997: 133-137) el possible rerefons real de l'aventura narrada, en la mesura en què sembla que hi havia hagut un seguit d'escàndols entre clarisses i framenors dels 
D'entrada, ja l'inici del poema ens posa en guàrdia. ${ }^{37} \mathrm{~L}$ 'acció s'inicia «Lay quant los gats van en amor / cridant e faent gran remor / per los taulats, / que par sien endiablats, / tant són cale[nts], / aferrant ab [ungl]es e dents / los l[urs] se[mblant]s / per lo tem[ps] [qui és] brau e frisants, / qui és ho[meyer]; / açò fo-n lo [me]s de gener / qui és mal [e] brau» (LfB 311,1-11). El lector actual potser se sorprèn de la imatge dels «gats calents», és a dir, en zel, sexualment excitats. És molt explícita. Però el receptor medieval devia sentir violada de manera immediata la tradició de centrar els temes amorosos en escenaris primaverals, descrits, normalment, a l'inici del poema. El primer poema que se'ns ha conservat, per exemple, del cançoner llatí de Ripoll és un cant a la primavera-joventut-amor: «Aprilis tempore, quo nemus frondibus / Et pratum roseis ornatur floribus / Iuuentus tenera feruet amoribus». ${ }^{38}$ I la tradició trobadoresca ens n'ofereix una mostra tan clara — que no n'és pas l'única-com la Kalenda maia de Raimbaut de Vaqueiras: "Kalenda maia / ni fueills de faia / ni chans d'auzell ni flors de glaia / non es qe.m plaia, / pros dona gaia, / tro qu'un isnell messagier aia / del vostre bell cors, qi.m retraia / plazer novell q'amors $m$ 'atraia [...]». ${ }^{39}$ Recordem també el famós romanç protagonitzat per un presoner que recorda la seva estimada en ple maig: «-Por el mes era de mayo cuando hace la calor, I cuando canta la calandria y responde el ruiseñor, / cuando los enamorados van a servir al amor, / sino yo, triste, cuitado que vivo en esta prisión [...]».40

convents de Girona i Vic. L'editor no proposa tant la trasllació a l'obra de fets concrets, sinó que les circumstàncies externes en fossin l'esperó: «El Libre de fra Bernat, però, reflecteix o, més ben dit, caricatura, no pas una realitat històrica concreta i particular, sinó un ambient $i$ unes circumstàncies. La narració no recolza en fets realment verificables [...]. És la sèrie d'episodis, com a conjunt, el que suggereix l'ambient on uns fets semblants serien possibles i el que subtilment ens fa cercar el context històric on un semblant ambient es podria esdevenir». La idea és versemblant, si bé difícilment demostrable, com ell mateix declara. D'altra banda, Pacheco actua massa condicionat per la seva voluntat de qualificar el text que ens ocupa com a obra realista. Per a ell, l'humor «dóna al text un to familiar i una interessant autonomia com a possible mirall i com a document de la realitat objectiva i quotidiana» (Via 1997: 38). Evidentment, segons el concepte de realisme que utilitzem, estarem més o menys d'acord amb la consideració d'aquesta obra com a mirall o document. Al meu parer, si tenim en compte el variadíssim ventall de tòpics damunt els quals es basteix l'obra, es fa difícil d'atorgar-li ni el més lleu caràcter documental o d'espill. I d'altra banda, que es constitueixi com a antítesi de la ficció trobadoresca, no vol dir que hagi de ser gaire més realista del que aquella era. Aquest divertit poema documenta simplement una manera de fer literatura diametralment oposada a la cortesa i trobadoresca i tan basada com aquella en uns determinats clixés i tòpics, entre els quals el riure obscè $i$ la paròdia tenen un pes determinant.

37 Totes les referències les faig a partir de Francesc de la Via (1997: 309-391), editat per Pacheco. M'hi referiré, a partir d'ací, com $L f B$ seguit de la indicació de pàgina i ratlla.

${ }^{38}$ Cito per l'edició bilingüe de Moralejo (1986: 148). El segon poema d'aquest mateix repertori, on es narra la primera vegada que l'autor va veure la seva amiga, també emmarca l'acció en maig (ibid.p. 160).

${ }^{9}$ Riquer (1983: vol. II, 836). Veg. més exemples trobadorescos en la introducció de Pacheco (Via 1997: 42, n. 13).

${ }^{40}$ Cito per l'edició de Díaz-Mas (1994: 284). Fins i tot els Planys del cavaller Mataró també al-ludeixen a aquest tòpic (Pacheco 1983: 204-205): «En l'asalt temps d'abril, / qui és temps dolç e gentil, / axí com és acostumats / e cells qui són enamorats / llavors deuen ésser jausents / pel temps qui és gay e plasents, / garnit de fulles e de flors, / qui dins lo cors porten dolçors / més que nulles saison de l'any, / on tot li dret e fin aimants / semeten tot jorn en tenir gais.» 
Calàndries, rossinyols i dolça calor del mes de maig que, per a començar, es converteixen en el Llibre de fra Bernat en gats, fred de gener i, si de cas, miols de gats eixits. I el clau queda ben reblat: «Aquest és lo mes qu'a nom, per ver, / d'anamorats; / ladonchs són tapats molts forats / e descusits» (LfB 312, 16-19). Les connotacions sexuals són òbvies, més encara si continuem llegint: ${ }^{41}$ la progressió avança des de l'al-lusió a «menar anques e costats» $(L f B 312,22)$ fins als ulls que es giren en blanc, als llavis - lambrots-que mosseguen llavis i, finalment, a «los genetius a grans colps / batre la porta» (LfB 312, 28-29). Sens dubte, no és aquest un poema construït des de la perspectiva de la fin' amors, encara que aquesta pugui ser un referent per a la burla, per al sarcasme: la paròdia sempre necessita un model extern. Es burla de l'amor cortès? A poc que anem llegint descobrirem que es burla de quasi tot, no pas sols dels delicats costums cortesos.

L'autor, convertit en coprotagonista de la seva història, es troba el dia d'any nou — «jorn de ninou»— amb fra Bernat, qui de seguida començarà a revelar-se com un religiós de pràctiques i conviccions més aviat peculiars, si més no. D'entrada, afirma que no pot dejunar més que de nits ( $L f B 315,94$ 95) «car mos spirits / no.u poden comportar». La impossibilitat de dejunar, automàticament el marca com una persona allunyada de l'ascetisme, ${ }^{42}$ de l'aspror de la vida monàstica. A més, dejunar implica saber controlar el cos: ja hem vist narracions $i$ textos que ho certifiquen $i$, per tant, no hi tornarem ací.

Recordem, en qualsevol cas, que la caiguda en la temptació de la gola va obligar el frare pecador protagonista de l'exemplum del Recull vist adés a caure en un altre pecat: la manca de domini sobre el cos pot portar d'un pecat a l'altre. Per tant, la incapacitat de fra Bernat per a practicar l'abstinència ja anuncia uns trets de caràcter que tot seguit van confirmant-se. La vocació sexual d'aquest frare també se simbolitza —es prefigura- amb el nom del monestir d'on prové: «frare so de sant Balluguet / d'Evall Empeny» ( $L f B$ 316, 112 113). I tot seguit, fra Bernat explica les grans virtuts que ornen la vida del sant patró d'aquest monestir: afirma que fa miracles molt grans, que «lay on fer / no-y pot curar nengun barber / ni nengun metge» $(L f B 316,119-120)$ i, a més, suporta quotidianament el martiri pels seus companyons, els quals intenta fer

41 Afirma Pacheco (Via 1997: 127): «El poema comença amb l'evocació d'una fórmula de la poesia trobadoresca per situar l'acció en un context temporal precís, però, com hem vist, en trenta versos escassament, el poeta transforma radicalment un tòpic tradicional per crear des del primer moment un clima essencialment despreocupat i llicenciós». Veg. els paral-lels que l'editor cita d'aquesta fórmula, ibid. pp. 42-43, i n. 13.

${ }^{42}$ De fet, un altre personatge ben allunyat de qualsevol model de virtut, el famós en Buc, declara també que no dejuna mai i que, quan ho ha fet, ha estat perquè la necessitat de fugir dels qui el perseguien l'obligaven a amagar-se fins a l'extrem de no poder menjar fins a la nit, moment en què se sentia segur: «Qué dius, cavall, dius que dejú? / E vist-me anc dejunar tu? / Digues, què acaba a Déu / l'endurar ne el dejunar meu? / No dejuní anc per mon grat; / verament ja he dejunat / con no havia què menjar, / con no havia què menjar, / que no em gosava demostrar / que estava tot jorn amagat / per tal com era bandejat, / mas puis com venia la nuit / no et pens que tingués peu en llit» (Pacheco 1983: 199). 
entrar «[...] al loch / on sovent entra» $(L f B 317,132-133)$. Tanmateix, els companyons l'abandonen sempre «e ell roman dins, tot destret, / faent gran dol, / per ço com la presó li tol / sos bons amichs / e per congoixa e destrichs / ve en suor, / e aquest beneÿt senyor / puys fortment plora, / per despler que $n$ ell demora / e per l'affany» ( $L f B 317,138-147)$. Potser seria exagerat pensar que aquesta anècdota s'ha construït reproduint en eco la pregària de Jesús a la muntanya de les Oliveres, però no pas per la possible irreverència, sinó perquè les connexions no són totals: es redueixen a la solitud d'un home sant, que és abandonat en una situació de perill i que, en tal situació, fa gran dol i ve en suor, elements que es donen en aquella referència evangèlica (Lc 22, 39-45, Mt 26, 36-46, Mc 14, 32-42). Ara, la cultura popular ens testimonia una situació semblant: «Debajo'el delantal / tengo yo un cuarto; / tiene sala y alcoba, / que es un encanto. / Como el cuarto es pequeño / y tres no caben, / dos se quedan afuera / y entra el más grande. Ya que el pobre ha logrado / lo que ha querío, / lo sacan los amigos / muy afligío». ${ }^{43}$

Fra Bernat continua explicant quina és l'activitat del seu convent ( $L f B 317$ $320,148-227)$ : embarassar les dones que no es poden quedar prenys dels seus respectius marits. Sembla, pel que comenta, que és una activitat que es practica amb gran dedicació i èxit, normalment. Aquest cenobi és tan antiimatge del que teòricament havien de ser els monestirs -independentment de la possible veracitat de certes anècdotes al rerefons d'aquesta situació- com també ho és la famosa Abadia de Thélème que funda un frare també molt peculiar en el Gargantua de Rabelais, on tampoc no hi havia res que pogués induir a l'ascetisme -almenys en el sentit més tradicional del terme-. ${ }^{44}$

Després de totes aquestes informacions, 1'autor acompanya fra Bernat cap al monestir de Devall Jau, perquè el frare hi té una monja, bellíssima, de la qual està enamorat. Precisament quan el frare descriu la seva estimada al cavaller s'expressa amb paraules corteses, cosa que ja contrasta si tenim presents les informacions que ens ha anat donant sobre ell mateix i el seu orde ( $L f B 321$ 322, 252-273): «Aquesta monja.m té en preson / e.m fa languir, / car tant l'am yo, que no ho sé dir / ne dar entendre. / Si li plagués me volgués pendre / per servidor, / presara-u més que ser senyor / de tota França. / En ella floreix e s'avança / tota proesa, / humilitat e gentilesa e bon capteny [...]» enumeració de virtuts plenes de tòpics fins, delicats, però que acaba amb un rotund: «e si li

43 Prenc aquesta referència de Cela (1989: II, 283).

44 Els capítols 52-57 del Gargantua de Rabelais (1994) ens descriuen la construcció de l'esmentada abadia, dissenyada amb la voluntat de representar una mena d'inversió dels convents habituals (Rabelais 1994: 137): «Il [= el monjo] requist à Gargantua qu'il instituast sa religion au contraire de toutes aultres». Aquest principi ho determina absolutament tot: no tindrà muralles, «car toutes aultres abbayes sont fierement murées» (ibid. p. 138) i, segons el frare amic de Gargantua, on hi ha mur «y a force murmur, envie, et conspiratiom mutue»; les dones que hi entrin - afirma irònicament el fundador - hauran de ser belles, ben formades i de bon caràcter; com que la vida dels covents està sempre del tot sotmesa al rellotge, en la nova abadia «feut decreté que là ne seroit horrologe ny quadrant aulcun» (ibid. p. 138). La millor síntesi del que significa aquest monestir és la llarga inscripció gravada sobre la gran porta de l'abadia (ibid. p. 141144). 
plagués que sots clau / ab ley dormís, / no ha tal goig en paradís / null confessor»..$^{45}$

Aquesta afirmació final provoca una resposta irada per part de l'autor-coprotagonista, que li recrimina la seva luxúria. El menoret se'n defensa tot al-ludint a la malaltia d'amor ( $L f B 322,276-279)$ : «-Sènyer, l'om qui és enamorat / no ha bon seny, / car fin' amor tant me destreny, / que tot marsesch.» L'autor contraataca des del camp de la moral religiosa i, llavors, el frare li respon utilitzant argumentacions amb autoritats i citacions pseudoescripturístiques, que imiten les pròpies d'un sermó, com ja havia fet Juan Ruiz, Arxiprest d'Hita, al començament del seu magnífic Libro de Buen Amor. ${ }^{46}$ Fra Bernat es justifica perquè actua segons la seva naturalesa ( $L f B$ 323, 298-301): «e-s eu suy tan acostumat / de ventres batre, / que, dins dos jorns, vint-e-quatre / colps n'ay donats». I, a més, considera que el seu treball és digne d'elogi perquè ho fa "per [e]xalçar crestiandat» $(L f B 323,310)$ i per fer infants. Més encara: quan l'autor li retreu el seu procedir i li recorda les penes de l'infern, fra Bernat treu a col-lació el bíblic «Crescite, multiplicamini».

Quan la conversa s'allarga amb massa reconvencions morals per part de l'autor, el frare talla en sec: el primer li havia preguntat si sabia què era pecat mortal i ell amolla, sense posar-se cap pedra al fetge ( $L f B 328,434-436)$ : «Aquell qui ab dona morta / jau carnalment, / aquest tal pecca mortalment / e fora mida». Aquest reduccionisme extrem es manifesta també en altres aspectes de la moral de fra Bernat. Per exemple, per a ell els qui fan mala vida són «Cells qui mengen sardes salades / e ayga.b pa» ( $L f B 329,454-455)$, amb la qual cosa de nou està tirant per terra la pràctica del dejuni. En aquest sentit, el nostre framenor podria ser bon amic del Bisbetó que en el seu sermó afirma, excusantse amb el fet de ser encara un xiquet (Pacheco 1983: 179) «mas fóra bo que d'un capó / alegrement / me dinàs per lo jovent / ab salsa fina, / més l'am cert que una sardina / de les salades».

No és l'única coincidència amb el sermó de l'Episcopus Puerorum: també hi està d'acord en la visió de les dones. Fixem-nos que, quan l'autor veu la monja, es queda captivat, embadalit i vençut per la seva immensa bellesa ${ }^{47}$ alhora que s'adona de com la religiosa xerra tranquil-lament amb un cavaller i no para esment en fra Bernat. Li ho fa veure, se’n burla i arriba a dir-li «-Frare, fort suy

45 Vegeu també com descriu la seva estimada al cavaller — quan, a més, vol prendre'n segurança que aquest no intentarà seduir-la — ( LfB 330, 478-487): «mostrar-vos hay ma especial / com és tan bella, / blanxa graciosa, isnella, / ab cors gentil; / e sab bé tenir lo dret estil / de saviesa, / e per sa gran gentilesa, / gint acullir; / a totes gents se fa grasir / per sa valor.»

46 Recordem el pròleg on l'arxiprest castellà intenta definir el concepte de «Buen Amor», construït com un sermó a partir d'un tema bíblic - «Intellectum tibi dabo...» (Ps 32 (31), 8)—, on repetidament remet a autors clàssics i a textos bỉblics, i la famosa cuaderna 71 on, bo i citant Aristòtil, afirma que «el mundo por dos cosas trabaja: la primera / por aver mantenencia; la otra cosa era / por aver juntamiento con fembra plazentera.»

${ }^{47}$ Observem com són de clares le seves paraules ( $\left.L f B 332,528-539\right)$ : «e quan eu viu so cors delgat / e tan adorn, / fui pus calent que si-n un forn / fos eu pausats, / car ab sos esgarts biaixats / llancec tals darts, / que no.m defès enginy ne arts / que no·m farís / d'una dolçor que $\cdot n$ paradís / cuydey estar / car eu pensí que deu passar / totes les belles». 
meravellat d'aquesta monja; / menys vos presa qu'un troç d'esponja, / segons que.m par, / car no us ha volgut saludar / ni dir paraula / Tot vostre bufar par qu.és faula, / segons que vey» ( $L f B 333,552-559)$. El menoret, dolgut i mossegat en el seu orgull, Ii amolla $(L f B 333,560-565)$ : «-Sènyer, totes dones, so crey, / par són horades; e juguen a les cambiades / axí co·ls plau; e porten l'om axí com fals dau, / al jugador». Aquesta idea la subratlla més avall quan diu que les dones «[...] fan hom pescar les lunes / ab un crivell / encar' ab fort petit simbell / caure en laçol; puys fan tenir hom lo cresol / al mig del dia» (LfB 352, 1048-1050). Precisament aquesta darrera comparació és també aprofitada pel Bisbetó (p. 191) quan parla especialment de les monges: «e fan llurs [=als homes] tenir al mig del jorn / lo llumener». ${ }^{48}$

El que sembla indubtable és l'atracció que exerceix la monja sobre fra Bernat (LfB 332, 544-545): «Dix lo frare: -Qui li pogués batre / lo seu broquer!». I ara ja sabem que l'autor comença també a sentir-se'n atret .

Amb l'aparició en l'escena de l'estimada de fra Bernat, aquesta es converteix en centre de l'acció. Fins i tot, encara que tinguem els protagonistes en primer pla, aquests parlen sense treva de la monja, que, a més, tenen a prop i vigilen, en un estat d'exasperació progressiva, atès que la religiosa no para de conversar amb els altres dos pretendents.

En realitat, la religiosa està negociant amb els seus amants, motiu narratiu que serveix per a oferir-nos una realització del conegut tòpic de la versatilitat $\mathbf{i}$ volubilitat femenina. L'autor ens conta que fa l'espieta $i$, gràcies a això, assistim a com la monja rebutja el cavaller com a pretendent - que s'expressa de manera absolutament cortesa ( $L f B$ 336-338, 648-705) -, al-legant l'excusa que és esposa de Jesucrist $(L f B 337,656-669),{ }^{49}$ fins que aquest li fa algun present: «dins un drap de li / una copa tota d'aur fi embolicada, / e crech l'haguessen obrada tota lay en París; / e puys hac mès cinc-cents florís / dins en la copa» ( $L f B$ 338-340, 706-741). Davant arguments de tant de pes, «La monja-s féu un poch tenir / e.s fech pregar, / mas l'aur la féu fort escalfar / fora mida [...]». A la mon-

${ }^{48}$ No oblidem que l'Infant-Bisbe passa revisió crítica, en el seu sermó, en principi a tots els estaments socials, però para una atenció en les dones clarament desproporcionada respecte als altres objectius de la seva sàtira. Tinguem en compte que el bescantament del sexe femení era ja quasi un tòpic, un simple joc, d'èxit gairebé assegurat. El jove bisbe narra (Pacheco 1983: 184-185) com una dona ha volgut convèncer-lo — subornant-lo i tot, amenaçant-lo més o menys indirectament - perquè no vituperi el sexe femení en el seu sermó. Quan ja s'havia deixat convèncer, rep la visita dels marits de les dones, demanant-li, també amb regals, exactament el contrari: que malparli de les dones. Estant així les coses, el Bisbetó no s'hi pensa i accedeix a la petició dels marits - justificant que parla de coses que ell mateix ha vist encara que sigui xiquet-. A partir d'ací teixeix un llarguíssim discurs on deixa anar els tòpics més coneguts de la literatura misògina, molts d'ells retrobables en l'Spill de Roig, obra en la qual el protagonista narra també la seva experiència matrimonal amb una donzella, una beguina, una viuda i una monja. Aquest esquema és bastant pròxim al seguit pel bisbetó en la seva predicació, on es refereix successivament a les dones, en general, i a les «placeres», en particular; a les viudes, a les monges i a les beates.

49 Convé recordar que també en l'Spill (Roig 2006: 256-259, 5.620-5.722, i comentari pp. 667668 ) trobem una monja que s'autodescriu com a esposada de Crist, fet que fa fugir el jove que ella perseguia per tal com no vol posar banyes a Déu. 
ja ja només li falta protegir-se de les enraonies de les males gents, alhora que pren la copa i els diners... I tan bon punt plega el cavaller, arriba el canonge, amb qui es repeteix una escena més o menys semblant - bé que l'argument/regal emprat és ara una mica diferent-.

$\mathrm{Si}$, d'una banda, aquestes negociacions serveixen per a donar pàbul a la mordacitat de fra Bernat - que arriba a esclatar a punys amb el canonge-, també adoben el camp per a la brutal paròdia que aquest prepara a la seva estimada. És clar que fra Bernat no vol ser menys, i vol presentar-li un regal convincent. En el transcurs d'una violenta disputa, el menoret li descobreix el seu present (LfB 370, 1526-1553): «Ladonchs mès mans a la braga, / mostrà-li son rava. / La monja-s mostrà fort brava / a fra Bernat, / quant viu son matràs ben format / $\mathrm{e}$ stech drets, / car n'hac un gran pal e tres dets, / ab gran esquena, / sí que'l clarejava la vena / d'un tret de dard, / que no.y havia null embarch, / drap ni cortines. -Han tal bech vostres gallines? /- dix fra Bernat; / lo qual li offer de bon grat / lo dit present, / que estech arborat fermament, / pus dur que ferra; / les palles llevà de terra / per gran calor. / La monge-s mudà de color / quan viu la birla, / sí que parec fos esmirla / detràs copada; / fonch-se ab vel emborraçada / denant la vista /e no.us pensets que fos trista, / ans la viu riure.»

Malgrat l'observació de l'autor i la sincera rialla de la monja, el menoret perd la partida. Tota aquesta escena, s'ha esdevingut immediatament després d'una llarga contesa verbal entre la monja i el framenor on també ha aparegut la ja coneguda oposició entre l'amor del cavaller i la del religiós, discussió a la qual fra Bernat ha volgut posar fi amb el seu generós regal.

Veiem, doncs, com aquesta obreta, assimilable amb les matisacions que alguin als fabliaux, ha estat capaç de fagocitar, a través de la paròdia, uns models textuals i temàtics determinats als quals ha respost de manera còmica. N'hem vist uns quants: la subversió del tòpic del locus amoenus o de la localització primaveral de l'amor, la mescla còmica d'elements cortesos amb elements pornogràfics, la diatriba cavaller/clergue en matèria amorosa, el discurs misogin en boca de l'amant menystingut, la victòria inesperada d'un tercer. I tot plegat, com diu la conclusió en prosa de l'obreta, únicament «per pendre solaç» $(L f B 391) .^{50}$ Tot plegat, hi trobem una línia temàtica i estilística que perdurarà a la València de les darreries de l'Edat Mitjana i que arribarà al màxim amb una obra mestra polèmica i encara difícil d'entendre: l'Spill de Jaume Roig.

50 Malgrat el que es declara a l'esmentat colofó $\longrightarrow$ on hom al-ludeix els «engans e burles / que les dones males, / e no les bones, / solen fer» $(L f B 391)-$, m'atreviria a dir que la diatriba misogina hi té un paper secundari. Certament, la monja mostra la seva mestria a l'hora de fer i desfer, enganyar i aconseguir el que vol, del tot fonametal en el desenvolupament de la narració, i s'adiu molt bé amb un dels models negatius de dona, com ja hem comentat més amunt. La personalitat de fra Bernat, però és tan ben definida i impacta tant des de l'inici per la seva constant xerrameca, que la monja quasi queda desdibuixada al seu costat. En qualsevol cas, el colofó no deixa de ser un tòpic més. 


\section{BIBLIOGRAFÍA}

Alvar, M. (1985): Antigua poesía española lírica y narrativa, México, Editorial Porrua.

Alzieu, P. + Lissorgues, Y. (1984): Poesía erótica del Siglo de Oro, Barcelona, Crítica.

ARNAU DE LiEJA (2004): Recull d'exemples $i$ miracles ordenat per alfabet, ed. i estudi de J.-A. Ysern, Barcino, 'ENC', 2 vols.

BAJTIN, M. (1987): La cultura popular en la Edad Media y en el Renacimeinto, Madrid, Alianza Universidad.

Bravo, J. A. (2001): Olla de curas, Barcelona, Ediciones Barataria, 'Inferno'.

Caro Baroja, J. (1985): Las formas complejas de la vida religiosa. Siglos XVI y XVII, Madrid, Sarpe.

Cela, C. J. (1989): Diccionario secreto, Madrid, Alianza Editorial, 3 vols.

CelA, C. J. (1994): Enciclopedia del erotismo, Madrid, Grupo Libro 88, 5 vols.

CHABÁs, R. (1902-1903): «Estudio sobre los sermones valencianos de S. Vicente Ferrer que se conservan manuscritos en la biblioteca de la Basílica Metropolitana de Valencia», Revista de archivos, bibliotecas y museos, núms. 6, 7, 8 i 9, pp. 1-6, 155$168 ; 131-142,419-439 ; 38-57,111-126,291-295 ; 85-102$. Tiratge separat per la $T i$ pografia de la Revista de archivos, bibliotecas y museos, ara dins: Roque Chabás. Opúsculos, ed. de M. Rodríguez Lizondo, València, Generalitat, Consell Valencià de Cultura, 1995.

DD. AA. (2000): Cancionero moderno de obra alegres, Barcelona, Alta Fulla.

DíaZ-Mas, P. (ed.) (1994): Romancero, Barcelona, Crítica.

DíEZ, F. (2003): La poesía erótica de los Siglos de Oro, Madrid, Ediciones Laberinto, Arcadia de las Letras.

EIXIMENIS, F. (1983): Lo crestià, tria, edició i introducció d'A. G. Hauf, Barcelona, Edicons 62 i La Caixa, 'MOLC'.

Fenollar, B. + Gassull, J. et alii (1988): Lo procés de les olives. Lo somni de Joan Joan, pròleg de S. Jàfer i edició de V. Pitarch i Ll. Gimeno, València, Tres i Quatre, 'L'estel'.

FERNÁNDEZ DE MORATíN, N. (1999): El arte de las putas, Valencia, La máscara.

FERrER, Vicent (1973): Sermons de quaresma, ed. de M. Sanchis Guarner, València, Clàssics Albatros, 2 vols.

FERrer, VicEnT (1932-1988): Sermons, 6 vols., ed. de J. Sanchis Sivera - G. Schib, Barcelona, Barcino, 'ENC'.

Frenk, M. (2006): «Curas y frailes en el cancionero popular del Siglo de Oro», Poesís popular hispánica. 44 estudios, México.

FuSTER, J. (1985): Literatura catalana contemporània, Barcelona, Curial.

FUSTER, S. (2004): «Timete Deum». El Anticristo y el final de la historia según S. Vicente Ferrer, València, Ajuntament, València. 
Gaignebet, Cl. (1984): El carnaval. Ensayos de mitología popular, Barcelona, Alta Fulla.

García-VILloslada, R. (1975): La poesía rítmica de los goliardos medievales, Madrid, FUE.

Góngora, L. DE (1980): Letrillas, ed. i intr. de R. Jammes, Madrid, Clásicos Castalia.

HAUF, A. (2000) L'home que riu: Entorn a la paròdia medieval, Manacor, Papers de sa Torre, 'Aplecs de cultura i ciències socials', núm. 54.

Hilka, A. + Schumann, O. (eds.) (1930): Carmina Burana, mit Benutzung der Vorarbeiten Wilhelm Meyers, Heidelberg, Carl Winter, 2 vols. (vol I: Text; vol. II: Kommentar).

JANER MANILA, G. (1982): Sexe i cultura a Mallorca: la narrativa oral i el teatre, Palma de Mallorca, Moll.

Janer Manila, G. (2003): Sexe i cultura a Mallorca: el cançoner, Palma de Mallorca, Moll.

LADERo QuesadA, M. Á. (2004): Las fiestas en la cultura medieval, Barcelona, Areté. $L f B$ : Veg. Via (1997).

Llop Català, M. (1995): San Vicente Ferrer y los aspectos socioeconómicos del mundo medieval, València, Ajuntament.

López de Ayala, P. (1982): Libro rimado del Palaçio, Madrid, Alhambra.

LOREnzo, A. (1997): Cuentos anticlericales de tradición oral, Valladolid, Ámbito Ediciones.

MARTÍNEZ, T. (2003): «Reflexions sobre la categorització del Cançoner satirich valencià de Miquel i Planas», Caplletra, núm. 34, pp. 111-126.

Martínez Sarrión, A. (1997): Poesía satírica española. Antología, Madrid, Espasa Calpe.

Metge, B. + Turmeda, A. (1927): Obres menors, ed. a cura de M. Olivar, Barcelona, Barcino, 'ENC'.

Moga, E. (2001): Los versos satíricos, Barcelona, Ediciones Robinbook, 'Ma non troppo'.

Moralejo, J.-L. (ed.) (1986): Cancionero de Ripoll, ed. bilingüe, Barcelona, Bosch.

Mullet, M. (1990): La cultura popular en la Baja Edad Media, Barcelona, Crítica.

Narbona, R. (1992): Pueblo, poder y sexo. Valencia medieval (1306-1420), Valencia, Diputació de València.

OTtaiAnO, A. (1993): «Els fabliaux catalans: anàlisi d'una definició», dins: A. Ferrando + A. Hauf (eds.) Miscel-lània Joan Fuster, vol. VII, Barcelona, PAM, pp. 5-43.

PACHECO, A. (1983): Blandín de Cornualla i altres narracions en vers dels segles XIV I $X V$, Barcelona, Edicions 62 i la Caixa, 'MOLC', núm. 96.

Pitarch, V. + Gimeno, Ll. (1982): Poesia eròtica i burlesca dels segles XV i XVI, València, Tres i Quatre. 
Pla, J. (2001): Notes disperses, Barcelona, Destino, Obra Completa, vol. 12.

PogGio, G. (1978): Llibre de facècies, pròleg i traducció de F. de B. Moll, Palma de Mallorca. Moll.

Prat, J. + Contreras, J. (1984): Les festes populars, Barcelona, Els llibres de la frontera.

Provencio, P. (2003): Antología de la poesía erótica española e hispanoamericana, Madrid, EDAF.

Puchades, R. J. (1999): Als ulls de Déu, als ulls dels homes, València, Universitat.

$\mathrm{Q}=$ Vid. Ferrer (1973): ed. Sanchis Guarner.

Quevedo, F. DE (1995): Poesía completa, ed. de J. M. Blecua, Madrid, Turner.

RABELAIS, F. (1994): La vie treshorrificque du grand Gargantua, dins: Oeuvres complètes, ed. de M. Huchon i F. Moreau, París, Gallimard.

RIQUeR, M. DE. (1983): Història d ela literatura catalana, vol. II, Barcelona, Ariel.

Robles, A. (ed.) (1996): Obras y escritos de S. Vicente Ferrer, Ajuntament, València.

RodríGuez, J. (ed.) (1989): Poesía crítica y satírica del siglo XV, Madrid, Clásicos Castalia.

RolG, J. (2006): Espill, ed. a cura d'A. Carré, Barcelona, Quaderns Crema.

Rosselló, R. + Bover, J. (1992): El sexe a Mallorca. Notes històriques, Palma de Mallorca, Miquel Font Editor.

Rossich, A. (1989): Poesia eròtica i pornogràfica catalana del s. XV'II, Barcelona, Quaderns Crema.

Rubio, J. E. (2004): Literatura política y moral práctica. Eiximenis, dins: www. liceus.com/cgi-bin/aco/lit/04/0100.asp.

Ruiz, J., ARCIPRESTE DE HITA (1990): Libro de Buen Amor, ed. de Jacques Joset, Madrid, Clásicos Taurus.

$S=$ Vid. Ferrer, ed. Sanchis Sivera + Schib (1932-1988).

Sagarra, J. M. ${ }^{a}$ de (2003): Poemes satírics, ed. de Ll. Permanyer, Barcelona, La Campana.

Simó, L. (ed.) (1999): Juglares y espectáculo. Poesía medieval de debate, Barcelona, DVD-Ediciones.

TuRmedA, A. (1928): Disputa de l'ase, Intr. de M. Olivar, versió cat. d' 'ENC', Barcelona, Barcino, 'ENC'.

URbano, M. (1999): Sal gorda. Cantares picantes del folklore español, Madrid, Hiperión.

VIA, F. DE LA (1997): Obres, ed. a cura d'A. Pacheco, Barcelona, Quaderns Crema.

VIA, F. DE LA Obres de Francesc de la Via (Llibre de fra Bernat inclòs) en: http://www.rialc.unina.it/inc-via.htm . 
VICTORIO, J. (1983): El amor y el erotismo en la literatura medieval, Madrid, Editora Nacional [reed. Madrid, editorial J. García Verdugo, 1995].

VILA, P. (1987): Bocavulvari eròtic de la llengua catalana [part medieval i renaixentista], Barcelona, El llamp; Bocavulvari... Segles XVIII, XIX i XX, Barcelona, Edicions de la Magrana, 'La marrana', 1990.

YSERN I LAGARDA, J.-A. (2003): «Sant Vicent Ferrer: Predicació i societat». Revista de filología románica, núm. 20, pp. 73-102. 